\title{
Inhibition of Bacterial Adhesion and Antibiofilm Activities of a Glycolipid Biosurfactant from Lactobacillus rhamnosus with Its Physicochemical and Functional Properties
}

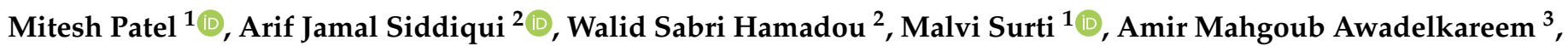 \\ Syed Amir Ashraf ${ }^{3}{ }^{\circ}$, Mousa Alreshidi ${ }^{2}{ }^{(0}$, Mejdi Snoussi ${ }^{2}{ }^{\oplus}$, Syed Mohd Danish Rizvi ${ }^{4}$, Fevzi Bardakci ${ }^{2}$, \\ Arshad Jamal ${ }^{2}$, Manojkumar Sachidanandan ${ }^{5}$ and Mohd Adnan ${ }^{2, *}$ (i) \\ 1 Bapalal Vaidya Botanical Research Centre, Department of Biosciences, Veer Narmad South Gujarat University, \\ Surat 395007, India; patelmeet15@gmail.com (M.P.); malvisurti92@gmail.com (M.S.) \\ 2 Department of Biology, College of Science, University of Hail, Hail P.O. Box 2440, Saudi Arabia; \\ arifjamal13@gmail.com (A.J.S.); walidsabrimail@gmail.com (W.S.H.); mousa.algladi@gmail.com (M.A.); \\ snmejdi@yahoo.fr (M.S.); fevzi.bardakci@gmail.com (F.B.); arshadjamalus@yahoo.com (A.J.) \\ 3 Department of Clinical Nutrition, College of Applied Medial Sciences, University of Hail, \\ Hail P.O. Box 2440, Saudi Arabia; mahgoubamir22@gmail.com (A.M.A.); \\ check for \\ updates \\ Citation: Patel, M.; Siddiqui, A.J.; \\ Hamadou, W.S.; Surti, M.; \\ Awadelkareem, A.M.; Ashraf, S.A.; \\ Alreshidi, M.; Snoussi, M.; \\ amirashrafy2007@gmail.com (S.A.A.) \\ 4 Department of Pharmaceutics, College of Pharmacy, University of Hail, Hail P.O. Box 2440, Saudi Arabia; \\ syedrizvi10@yahoo.com \\ 5 Department of Oral Radiology, College of Dentistry, University of Hail, Hail P.O. Box 2440, Saudi Arabia; \\ smanojk68@gmail.com \\ * Correspondence: drmohdadnan@gmail.com
} Rizvi, S.M.D.; Bardakci, F.; et al. Inhibition of Bacterial Adhesion and Antibiofilm Activities of a Glycolipid Biosurfactant from Lactobacillus

rhamnosus with Its Physicochemical and Functional Properties. Antibiotics 2021, 10, 1546. https://doi.org/ 10.3390/antibiotics10121546

Academic Editors: Tomasz Janek,

Anna Kancelista

and Barbara Żarowska

Received: 6 November 2021

Accepted: 16 December 2021

Published: 17 December 2021

Publisher's Note: MDPI stays neutral with regard to jurisdictional claims in published maps and institutional affiliations.

Copyright: (c) 2021 by the authors. Licensee MDPI, Basel, Switzerland. This article is an open access article distributed under the terms and conditions of the Creative Commons Attribution (CC BY) license (https:// creativecommons.org/licenses/by/ $4.0 /)$.
Abstract: Biosurfactants derived from different microbes are an alternative to chemical surfactants, which have broad applications in food, oil, biodegradation, cosmetic, agriculture, pesticide and medicine/pharmaceutical industries. This is due to their environmentally friendly, biocompatible, biodegradable, effectiveness to work under various environmental conditions and non-toxic nature. Lactic acid bacteria (LAB)-derived glycolipid biosurfactants can play a major role in preventing bacterial attachment, biofilm eradication and related infections in various clinical settings and industries. Hence, it is important to explore and identify the novel molecule/method for the treatment of biofilms of pathogenic bacteria. In the present study, a probiotic Lactobacillus rhamnosus (L. rhamnosus) strain was isolated from human breast milk. Firstly, its ability to produce biosurfactants, and its physicochemical and functional properties (critical micelle concentration (CMC), reduction in surface tension, emulsification index (\% EI24), etc.) were evaluated. Secondly, inhibition of bacterial adhesion and biofilm eradication by cell-bound biosurfactants from L. rhamnosus was performed against various biofilm-forming pathogens (B. subtilis, P. aeruginosa, S. aureus and E. coli). Finally, bacterial cell damage, viability of cells within the biofilm, exopolysaccharide (EPS) production and identification of the structural analogues of the crude biosurfactant via gas chromatography-mass spectrometry (GC-MS) analysis were also evaluated. As a result, L. rhamnosus was found to produce $4.32 \pm 0.19 \mathrm{~g} / \mathrm{L}$ biosurfactant that displayed a CMC of $3.0 \mathrm{~g} / \mathrm{L}$ and reduced the surface tension from $71.12 \pm 0.73 \mathrm{mN} / \mathrm{m}$ to $41.76 \pm 0.60 \mathrm{mN} / \mathrm{m}$. L. rhamnosus cell-bound crude biosurfactant was found to be effective against all the tested bacterial pathogens. It displayed potent anti-adhesion and antibiofilm ability by inhibiting the bacterial attachment to surfaces, leading to the disruption of biofilm formation by altering the integrity and viability of bacterial cells within biofilms. Our results also confirm the ability of the L. rhamnosus cell-bound-derived biosurfactant to damage the architecture of the biofilm matrix, as a result of the reduced total EPS content. Our findings may be further explored as a green alternative/approach to chemically synthesized toxic antibiofilm agents for controlling bacterial adhesion and biofilm eradication.

Keywords: biosurfactants; Lactobacillus rhamnosus; gas chromatography-mass spectrometry; antibiofilm; anti-adhesion; exopolysaccharide; lactic acid bacteria; surface tension 


\section{Introduction}

In nature, the formation of biofilms on living and non-living materials is an aggregation of surface-related bacterial cells, which are encompassed in an extracellular polymeric substance matrix [1]. Within a biofilm, bacteria display dozens of attributes, which makes them hard to eliminate. In comparison to their planktonic forms, they are phenotypically different mainly in the expression of genes and growth rates [2]. Biofilms portray a protected form of growth, which make bacterial cells 1000-fold more resistant to antibiotics and the immune system of the host than the planktonic form. Consequently, biofilms make bacterial cells stay alive within unfriendly conditions and also to spread and inhabit new environments [3]. Many aspects contribute to this antibiotic resistance, such as changes in physiology, steady growth rate, neutralization of the antimicrobial agents and changes in expression of genes [4]. Other aspects, such as synthesis of extracellular polymers, the age of the biofilm, appearance of small colony variants and dysfunction of the local neutrophils, also play an immense role in the resistance of biofilm bacteria towards the antimicrobial agents [5-7]. Moreover, the presence of excessive cell densities within the biofilms significantly enhances the possibility of horizontal gene transfer, which enhances the probability of the appearance of strains with higher resistance or distorted virulence profiles [8].

Biofilms of bacteria are typically pathogenic and responsible for nosocomial infections. About 60 to $80 \%$ of chronic infections are due to the formation of biofilm. Presently, biofilm is a serious problem around the globe, which causes a severe impact and ultimately huge losses to the food, dairy, oceanic, aquaculture, beverage, environment and biomedical industries $[9,10]$. Therefore, biofilm removal is a global challenge that necessitates developing novel natural bioactive compounds to control biofilms, as an alternative to antibiotics or chemically synthesized agents.

Different types of microbes, such as bacteria, fungi, yeast, etc., non-ribosomally synthesize secondary metabolites in their resting and/or active growing stages, which are known as 'biosurfactants' [11-13]. On the basis of their microbial origin and chemical composition, biosurfactants are mainly classified into five classes, which includes polymeric compounds, neutral lipids, phospholipids, lipopeptides and glycolipids $[12,14]$. In the present time, biosurfactants are gaining attention from scientists for their application in different fields because of their eco-friendly properties, easy mass production, effectiveness under harsh environmental conditions, selectivity and diversity. Apart from their extensive application in the field of oil recovery, bioremediation and industrial emulsification, nowadays these compounds also display their application in the biomedical field as antimicrobials, anti-adhesives and anticancer agents [15-18].

Lactic acid bacteria (LAB), commonly known as 'probiotic bacteria', are usually presumed to have effective function in keeping good health and immunity in humans. They produce diverse imperative antimicrobial metabolites such as bacteriocins, bacteriocin-like compounds, lactic acid, hydrogen peroxide and biosurfactants, which have an immense number of applications in the biomedical field. Among them, biosurfactants are the important one, which can play a critical role in the inhibition of the adherence ability of numerous pathogens-an essential step for the formation and proliferation of biofilms [19]. Hence, biological compounds with antimicrobial properties and the capability to inhibit the adhesion potential of pathogens on different types of surfaces can be developed as a potent antibiofilm agent. Such biofilms of pathogenic bacteria commonly occur on catheters, silicon-based devices, cardiac devices, surgical wounds and other prostheses $[17,20]$. Numerous reports have been available on the biosurfactant production ability and application of those biosurfactants in the inhibition of adhesion of microbes, desorption activity and inhibiting the development of biofilm on variety of surfaces, such as silicone, rubber, polypropylene and different biomedical instruments/implants [21-30].

The biosurfactants derived from different probiotic LAB has extensive applications in these fields. Hence, in vitro assessment of biofilm development prevention or disruption by natural biosurfactants derived from probiotic LAB is a plausible approach that can lead to 
the discovery of novel antimicrobials. In the present study, probiotic LAB was isolated from human breast milk and a characterization of its functional ability, biosurfactant production and physicochemical properties was carried out. Furthermore, the biomedical potential (antibacterial, antibiofilm and anti-adhesive) of the cell-bound biosurfactant of the isolated LAB was also assessed against various biofilm-forming pathogens.

\section{Results}

\subsection{Identification and Screening of Promising Biosurfactant-Producing Lactic Acid Bacteria}

The probiotic LAB was isolated from a human breast milk sample on MRS agar plates. Based on the morphological and 16S rRNA sequence analysis, the isolated probiotic LAB was identified as L. rhamnosus. GenBank sequence database was used after the BLASTn homology run of the obtained nucleotide sequence of the strain MBP002. A more than 99\% sequence identity was matched with L. rhamnosus against the nucleotide sequence collection in the database. Following successful identification, the nucleotide sequence with accession number MZ496826 was deposited into GenBank database of NCBI.

L. rhamnosus is a member of the probiotic Lactobacillus genus, which is a short, rodshape, Gram-positive, homofermentative, facultative anaerobic. Originally, it was considered to be a subspecies of $L$. casei, but genetic research found it to be a separate species in the L. casei clade, which also includes L. paracasei and L. zeae [31-33]. Several changes have been made to the taxonomy of the L. casei group. In the approved lists of bacterial names [34], $L$. casei was categorized as a single species with five subspecies based on phenotypic features: L. casei subsp. casei, L. casei subsp. alactosus, L. casei subsp. pseudoplantarum, L. casei subsp. tolerans and L. casei subsp. rhamnosus. On the basis of DNA-DNA homology, this species was reclassified into three species and two subspecies [35]: (i) L. casei (including strains that previously belonged to L. casei subsp. casei); (ii) L. paracasei consisting two subspecies, L. paracasei subsp. paracasei (including the previous subspecies L. casei subsp. alactosus and L. casei subsp. pseudoplantarum) and L. paracasei subsp. tolerans (including the previous sucspecies L. casei subsp. tolerans); and (iii) L. rhamnosus (subspecies that were previously classified L. casei subsp. rhamnosus).

The biosurfactant-producing capability of the isolated L. rhamnosus cell-free solution was screened via different qualitative and quantitative assays. Firstly, a drop-collapse assay was performed, which is based on the droplet destabilization by surfactants. Accordingly, a drop of a cell-free biosurfactant solution of L. rhamnosus was dispensed on oil. On this occasion, if the surfactant is not present in the liquid, the drop stands stable, meaning, from the hydrophobic sites, the polar water molecules are repulsed. Contrastingly, if the surfactant is present in the liquid, the drop will collapse. This is due to the interfacial tension or force between the hydrophobic surface and liquid. In the case of L. rhamnosus, the flattened drop of the supernatant placed over the surface of the oil suggested the existence of a biosurfactant. Additionally, an oil-spreading assay was also performed as a confirmatory assay for the validation of the drop-collapse assay result. In this assay, the area of oil displacement is directly proportional to the concentration of surfactants. In the case of L. rhamnosus, the oil-spreading assay was conducted in relation to the diameter and time in which the L. rhamnosus cell-free biosurfactant solution revealed positive results (Table 1).

Table 1. Qualitative and quantitative results of the different screening assays for the production of biosurfactants (values are the mean $\pm \operatorname{SD}(n=3))$.

\begin{tabular}{cccccc}
\hline Strain & $\begin{array}{c}\text { Colony } \\
\text { Characteristics }\end{array}$ & Gram's Reaction & $\begin{array}{c}\text { Oil-Spreading } \\
\text { Test }\end{array}$ & $\begin{array}{c}\text { Drop-Collapse } \\
\text { Test }\end{array}$ & BAP Test \\
$\begin{array}{c}\text { L. rhamnosus } \\
\text {-MBP002 }\end{array}$ & $\begin{array}{c}\text { White, circular, } \\
\text { shiny } \\
\text { appearance }\end{array}$ & $\begin{array}{c}\text { Gram-positive, } \\
\text { rod shaped }\end{array}$ & Positive & Positive & Positive \\
\hline
\end{tabular}




\subsection{Growth Kinetics and Biosurfactant Production}

Biosurfactant production and extraction was carried out in MRS-Lac medium. Figure 1 represents the kinetic profile plot of biosurfactant production by L. rhamnosus in this medium. It displayed that the synthesis of biosurfactant was growth-dependent and took place in the log phase. A graph of the surface tension reduction was plotted. Moreover, cell biomass $(4.84 \pm 0.12 \mathrm{~g} / \mathrm{L})$, biosurfactant production $(4.32 \pm 0.19 \mathrm{~g} / \mathrm{L})$ and the highest reduction activity $(42.48 \pm 1.22 \mathrm{mN} / \mathrm{m})$ was found/noted when the cells entered in their stationary phase. Production of biosurfactant and the reduction in the surface tension were constant up to the termination point of the stationary growth phase.

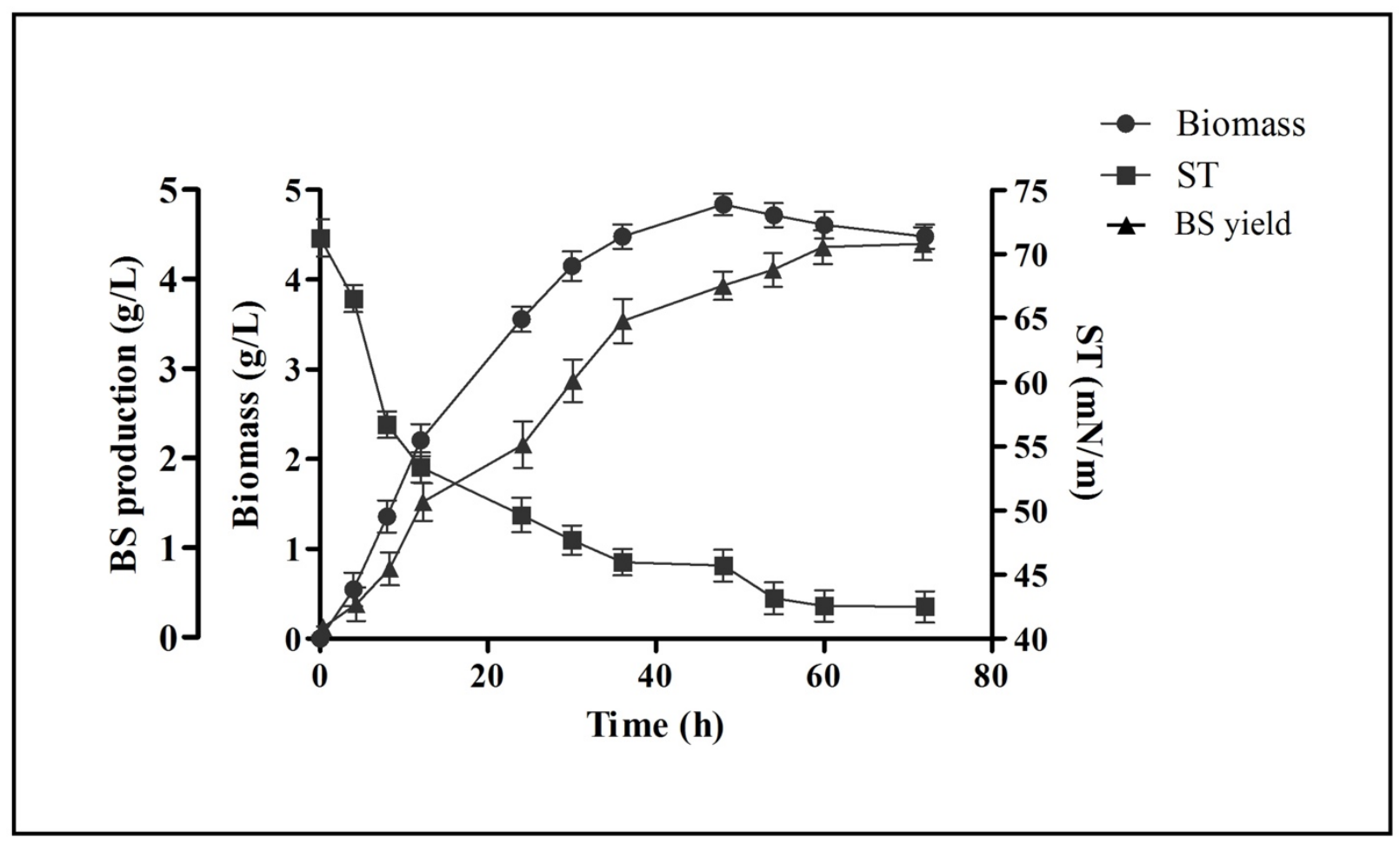

Figure 1. Profiling of the growth kinetics of L. rhamnosus in reference to the reduction in surface tension (ST) and production of biosurfactant (BS) at different time intervals. Values are the mean $\pm \mathrm{SD}$ of three independent experiments.

\subsection{Physical Properties of the Biosurfactant}

Decreasing the surface tension at the lowest CMC is one of the crucial attributes of an efficient biosurfactant. Extracted cell-bound biosurfactant was further evaluated for reduction in surface tension and CMC value by using a tensiometer (K11, Krus, Germany). A sudden break in the surface tension plot versus the plot of the biosurfactant concentration is defined as the CMC. The biosurfactant produced by L. rhamnosus reduced the surface tension from $71.12 \pm 0.73 \mathrm{mN} / \mathrm{m}$ to $41.76 \pm 0.60 \mathrm{mN} / \mathrm{m}$ at a CMC of $3.0 \mathrm{mg} / \mathrm{mL}$ (Figure 2A). Moreover, the biosurfactant produced by L. rhamnosus was also able to emulsify different hydrocarbon substrates, such as n-hexadecane, gasoline, diesel, kerosene, toluene, olive oil and sunflower oil. The highest \%EI24 was obtained for an n-hexadecane/biosurfactant emulsion (55.89 \pm 1.12$)$, while the lowest $\% E I 24$ was obtained for a sunflower oil/biosurfactant emulsion (35.65 \pm 1.31 ) (Figure 2B). 


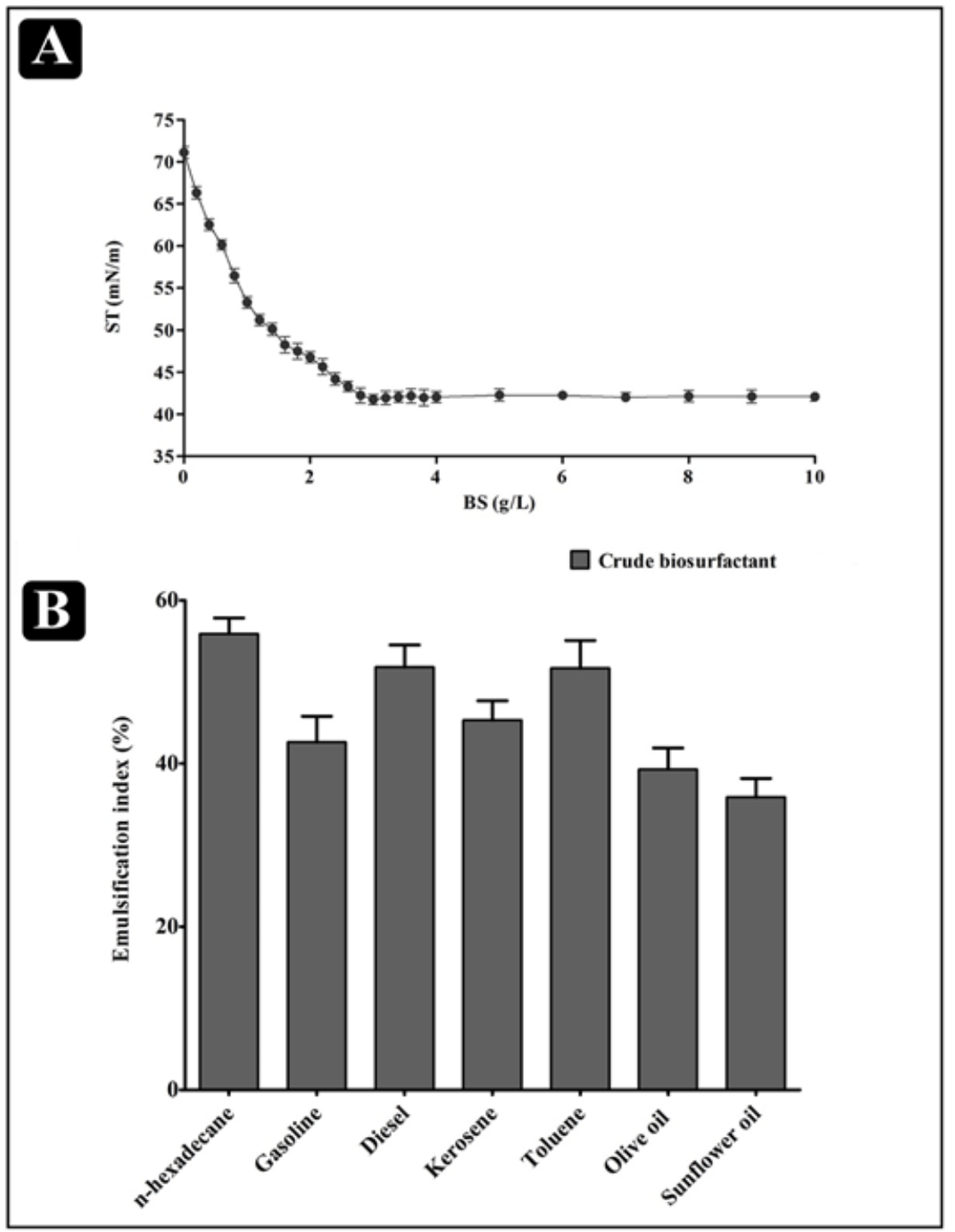

Figure 2. Results of the physical properties of the L. rhamnosus crude biosurfactant (BS). (A) Progressive decrease in surface tension (ST) with increase in concentration of biosurfactant up to $3.0 \mathrm{~g} / \mathrm{L}$. (B) \%EI24 of the cell-bound biosurfactant against different substrates. Values are the mean \pm SD of three independent experiments.

\subsection{Antibacterial Activity of the L. rhamnosus Crude Biosurfactant}

The inhibitory potential of the crude biosurfactant of L. rhamnosus and standard SDS (sodium dodecyl sulfate) was determined via the agar cup/well diffusion method against four different biofilm-forming human pathogens: Gram-negative E. coli and P. aeruginosa, and Gram-positive B. subtilis and S. aureus. Both the L. rhamnosus crude biosurfactant and standard SDS displayed considerable antibacterial effect against all the tested bacterial pathogens, represented in the form of the zone of inhibition (Figure 3A). The antibacterial potency of the L. rhamnosus crude biosurfactant and standard SDS was further evaluated by assessing the minimum inhibitory concentration (MIC) and minimum bactericidal concentration (MBC) against the test pathogens. The values of the L. rhamnosus crude biosurfactant MIC were ranged from 12.5 to $50 \mathrm{mg} / \mathrm{mL}$ and the $\mathrm{MBC}$ values were found two-times higher than the MIC values (Table 2). In turn, the values of the standard SDS MIC ranged from 0.2 to $0.8 \%$ and the MBC values from 0.4 to $1.0 \%$ (Table 2 ). 


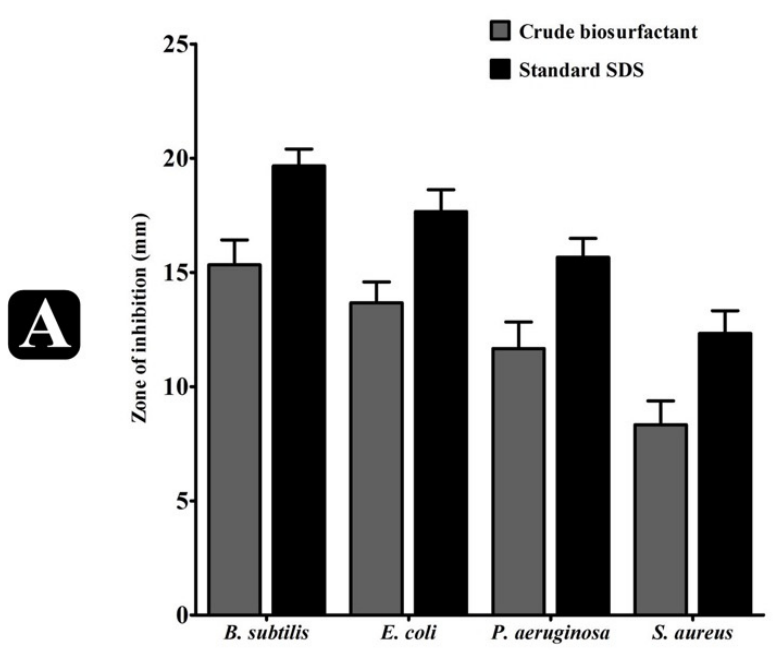

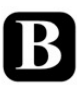

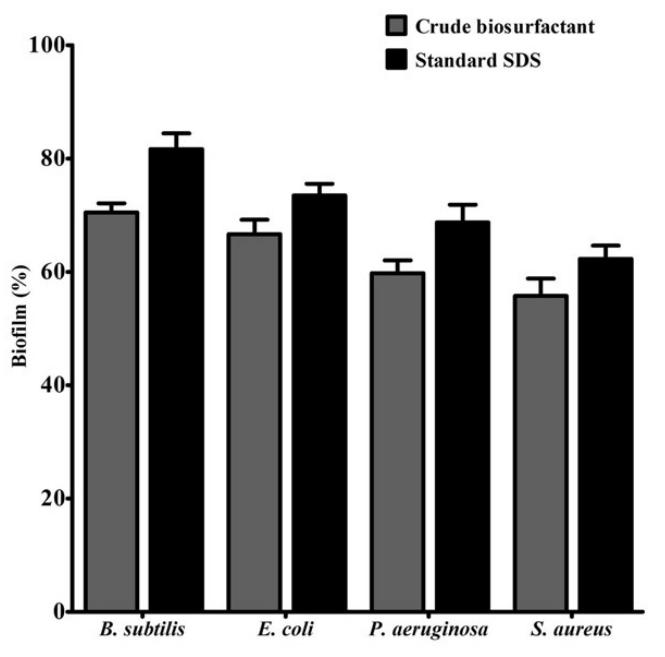

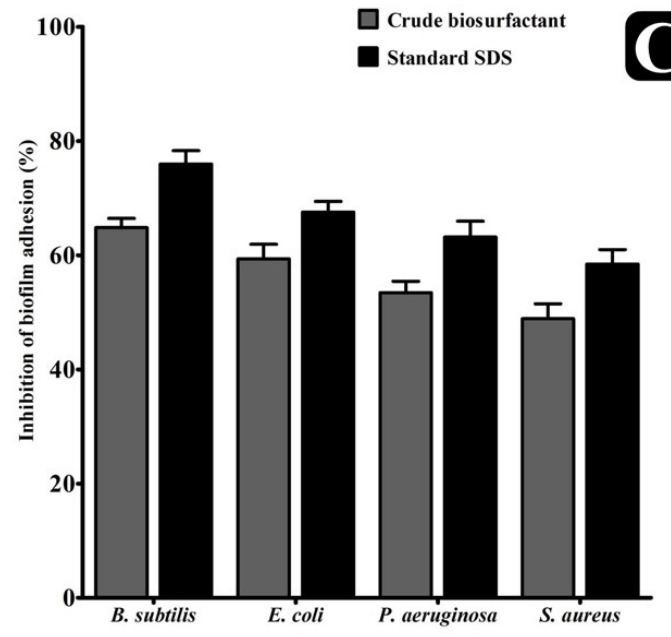

Figure 3. Results of the antibacterial, antibiofilm and anti-adhesion activity of the L. rhamnosus crude biosurfactant and standard SDS. (A) Antibacterial activity of the L. rhamnosus crude biosurfactant $(100 \mathrm{mg} / \mathrm{mL})$ and standard SDS surfactant $(1 \% v / v)$ against different bacterial pathogens. (B) Effect of the L. rhamnosus crude biosurfactant and standard SDS surfactant on established biofilms of different bacterial pathogens at their respective MICs. (C) Effect of the L. rhamnosus crude biosurfactant and standard SDS surfactant on the adherence ability of different bacterial pathogens at their respective MICs. Values are the mean \pm SD of three independent experiments.

Table 2. Antibacterial activity of the L. rhamnosus crude biosurfactant and standard SDS.

\begin{tabular}{ccccc}
\hline Bacterial Strain & L. rhamnosus Crude Biosurfactant $(\mathbf{m g} / \mathbf{m L})$ & \multicolumn{2}{c}{ SDS (\%) } & MBC \\
\hline MIC & MBC & 25 & 0.2 & 0.4 \\
E. coli & 12.5 & 25 & 0.4 & 0.6 \\
P. aeruginosa & 12.5 & 50 & 0.6 & 0.8 \\
S. aureus & 25 & 100 & 0.8 & 1 \\
\hline
\end{tabular}

\subsection{Antibiofilm Potential of the L. rhamnosus Crude Biosurfactant}

The antibiofilm potential of the L. rhamnosus crude biosurfactant and standard SDS was determined by its capability to impair the preformed biofilms of the test strains and inhibiting their adhesion ability to the surface. Our results showed that the L. rhamnosus 
crude biosurfactant and standard SDS efficiently disrupted the preformed biofilms with an ability to inhibit the adhesion potential of all test strains at MIC. At this concentration, the eradication of the preformed biofilms by the L. rhamnosus crude biosurfactant was about $70.49 \pm 0.92 \%$ for B. subtilis, $66.65 \pm 1.47 \%$ for E. coli, $59.78 \pm 1.30 \%$ for P. aeruginosa and $55.77 \pm 1.76 \%$ for $S$. aureus (vs. $81.65 \pm 1.61 \%$ for B. subtilis, $73.49 \pm 1.19 \%$ for $E$. coli, $68.72 \pm 1.80 \%$ for P. aeruginosa and $62.28 \pm 1.36 \%$ for S. aureus for standard SDS). The adhesion potential of the biofilms was also found to decrease with percentage of eradication, being $64.83 \pm 1.12 \%$ for B. subtilis, $59.23 \pm 1.47 \%$ for E. coli, $53.44 \pm 1.15 \%$ for P. aeruginosa and $48.88 \pm 1.42 \%$ for S. aureus (vs. $75.98 \pm 1.34 \%$ for B. subtilis, $67.53 \pm 1.08 \%$ for E. coli, $63.17 \pm 1.60 \%$ for P. aeruginosa and $58.43 \pm 1.47 \%$ for S. aureus for standard SDS) (Figure 3B,C).

\subsection{Effect of L. rhamnosus Crude Biosurfactant on Bacterial Cells Entrapped in Biofilms}

To explore the prospect that the L. rhamnosus crude biosurfactant could decrease the viability of bacteria within biofilms, an XTT (2,3-Bis(2 methoxy-4-nitro-5-sulfophenyl)-5[(phenyl-amino)carbonyl]-2H-tetrazoliumhydroxide) reduction assay and LDH (lactate dehydrogenase) activity was performed. The obtained results revealed that the viability of all bacteria inside the biofilms were remarkably reduced upon treatment of the L. rhamnosus crude biosurfactant, with different susceptivity (Figure 4A). Similarly, LDH activity was also assessed. LDH is the bacterial intrinsic intracellular enzyme that carries out the conversion of lactate into pyruvate and reverse. LDH activity is well-detected when the bacterial cell membrane is not intact. Our results indicated that, upon the treatment of the L. rhamnosus crude biosurfactant at the MIC level, LDH activity was found to be elevated in the supernatant of all the test strains. Higher LDH activity was found in B. subtilis, whereas lower activity was found in S. aureus (Figure 4B). Hence, such results evidently indicates that the L. rhamnosus biosurfactant could impair the bacterial cell membrane within the biofilms, eventually leading to bacterial death.

\subsection{Effect of the L. rhamnosus Crude Biosurfactant on Exopolysaccharide (EPS) Production}

EPS are biopolymers of bacterial origin and immersed within the biofilm. Biopolymers of EPS develops a matrix and are hydrated by retaining the water and keeps up the cells together within the biofilm. Our results displayed that the production of total EPS was considerably decreased in all test strains after treatment with the L. rhamnosus crude biosurfactant (Figure 5). 


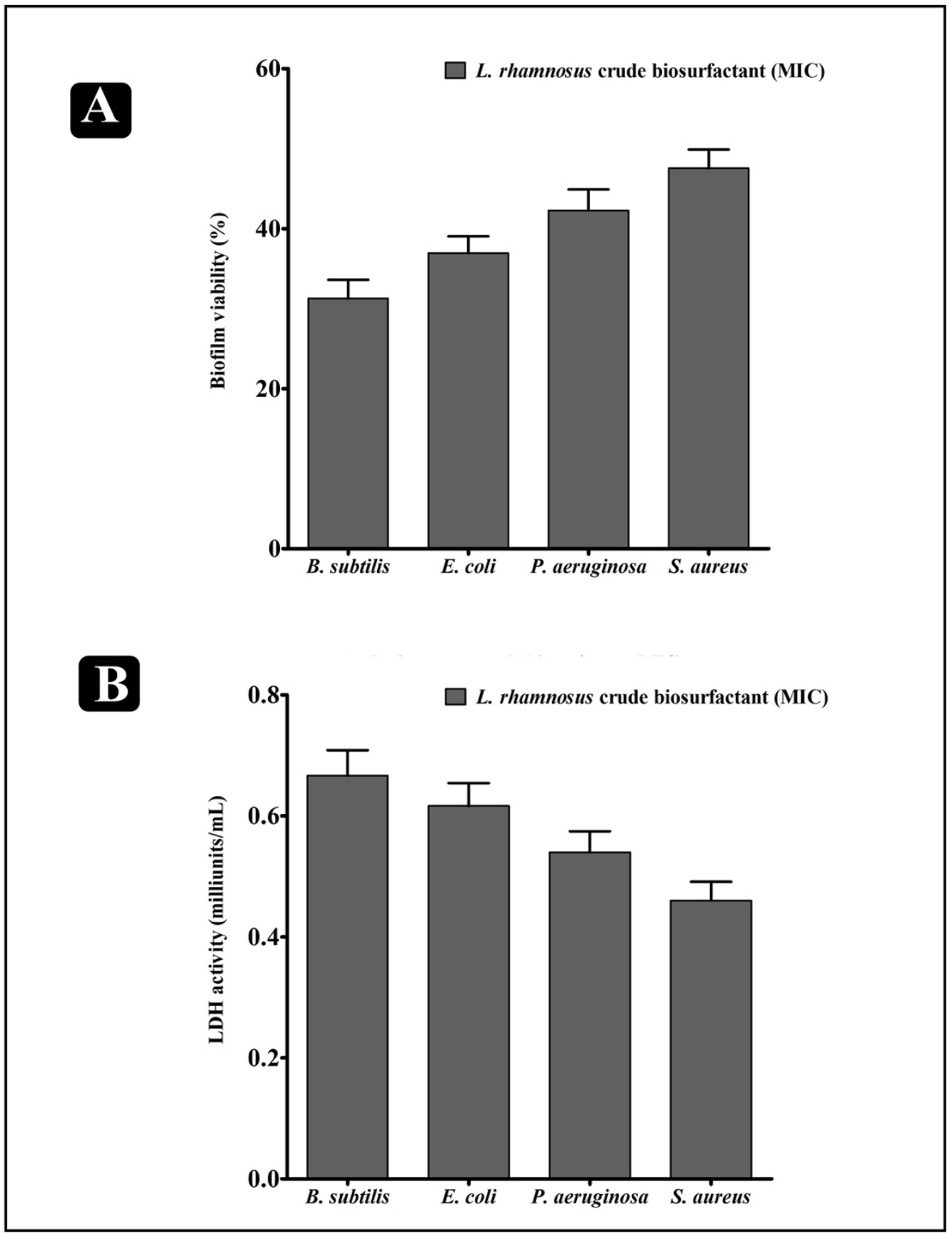

Figure 4. Results of XTT and LDH assays for confirming the antibiofilm potential of the biosurfactant (A). Percentage of bacterial viability within biofilms determined by XTT assay at the respective MICs. (B) Bacterial cell damage within the biofilm, based on LDH activity upon the treatment of the L. rhamnosus crude biosurfactant at the respective MICs. Values are the mean \pm SD of three independent experiments. 


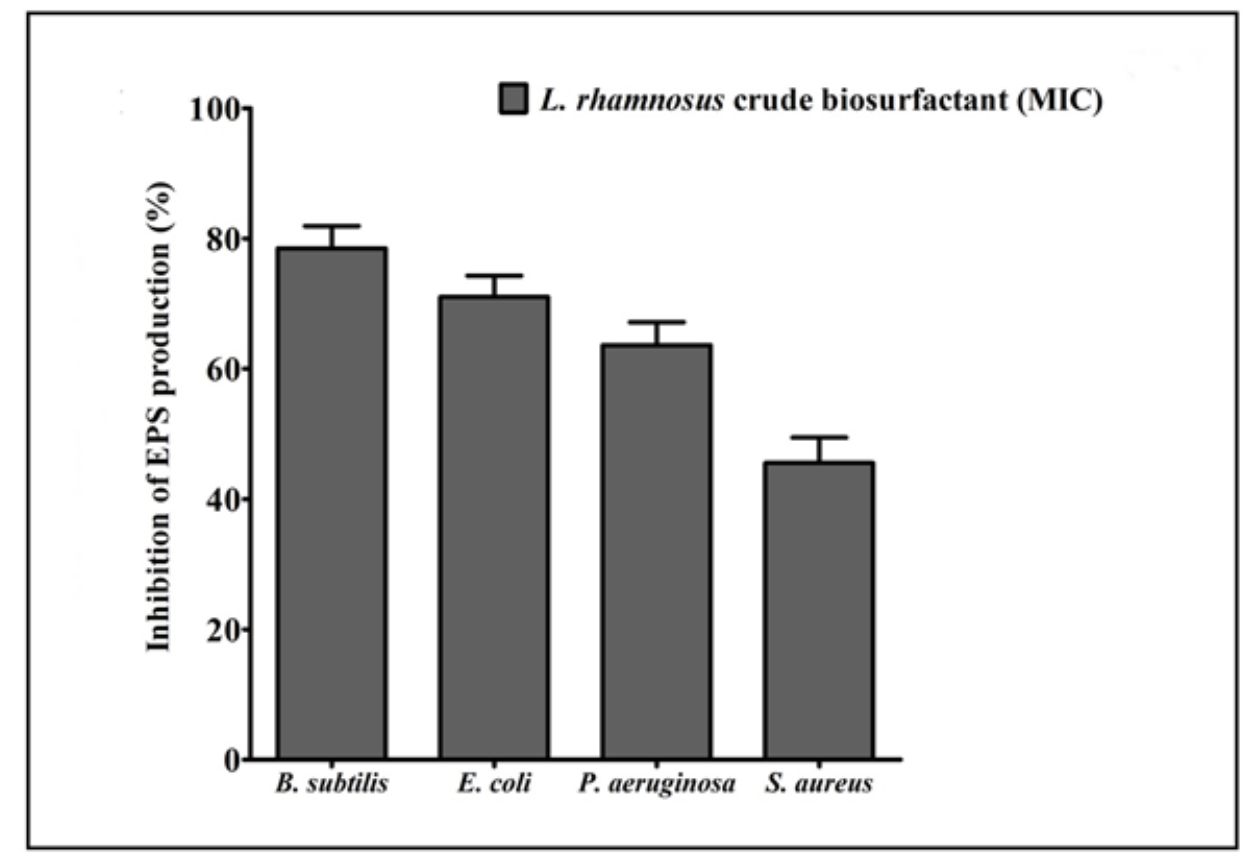

Figure 5. Inhibition of the total EPS production by the test pathogens in the presence of the L. rhamnosus crude biosurfactant at their respective MICs. Values are the mean $\pm \mathrm{SD}$ of three independent experiments.

2.8. Microscopic Analysis for the Visualization of the Disrupted Biofilms by Light (LM) and Scanning Electron (SEM) Microscopy

The efficiency and level of biofilm disruption of the test strains by the L. rhamnosus crude biosurfactant at its MIC was investigated under LM and SEM. Under light microscopy, the control sample displayed a heavy-knit-like mat of biofilms, while in the presence of the L. rhamnosus crude biosurfactant, deterioration in biofilm thickness with lower appearance of micro colonies was observed (Figure 6). Similarly, the biofilm anatomy and surface morphology were confirmed by SEM analysis in the presence and absence of the L. rhamnosus crude biosurfactant. In the control group of samples, multi-tiered biofilm growth was seen, while the treatment group with the L. rhamnosus crude biosurfactant displayed a reduction in thick aggregation of the tested bacterial cells (Figure 7). This might be due to the impairment of the EPS layer present in the biofilms. These results were further confirmed by the performed EPS assay. Our results of the EPS assay displayed a remarkable reduction in the EPS production of all the test strains treated with the $L$. rhamnosus crude biosurfactant. Altogether, our results have evidently demonstrated the effectiveness of the L. rhamnosus crude biosurfactant as a potential, natural and green antibiofilm agent. 


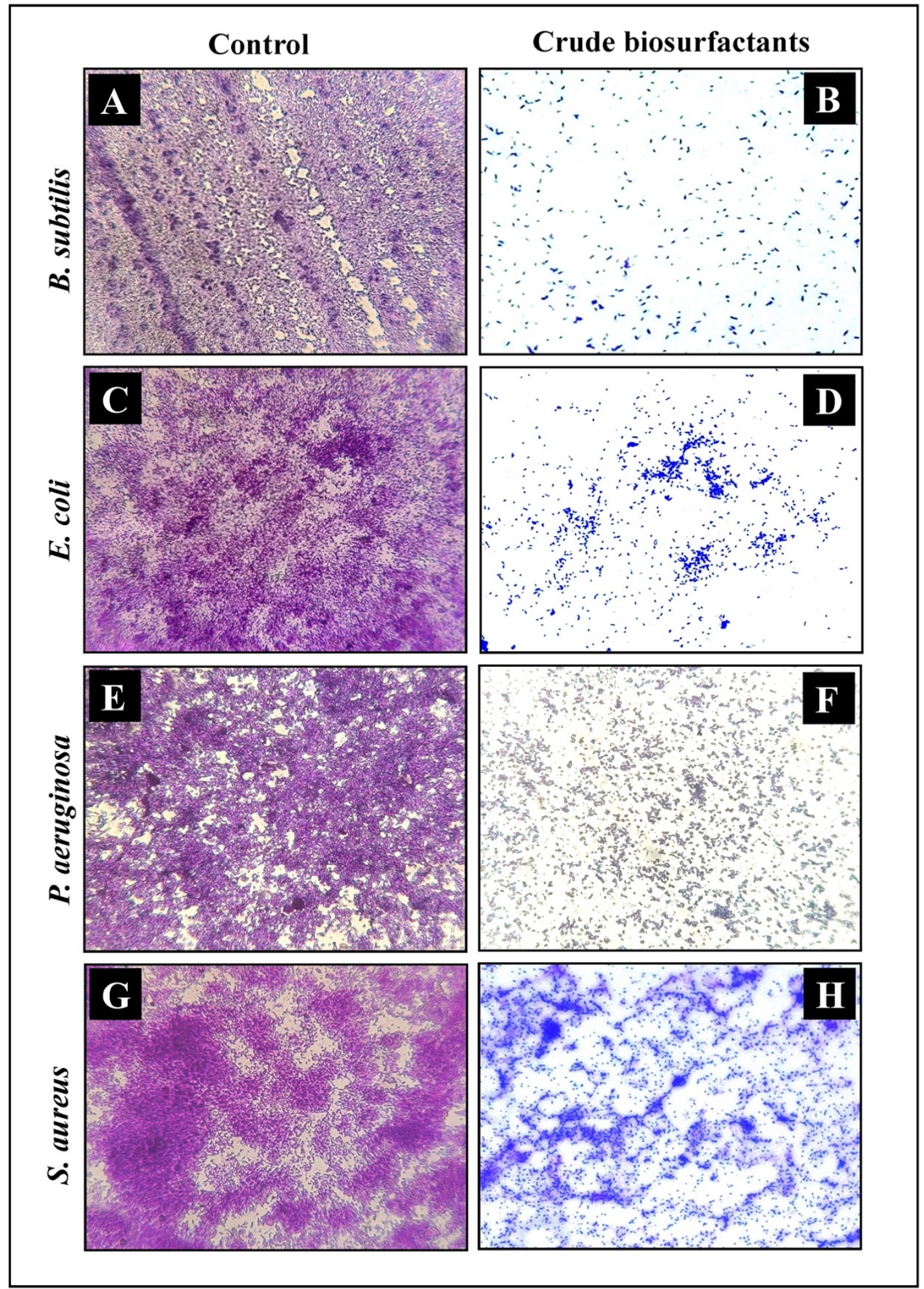

Figure 6. Micrographs of the disrupted matured biofilms of the test pathogens by the L. rhamnosus crude biosurfactant formed on a glass surface at their respective MICs under LM. Growth control (A,C,E,G); with the L. rhamnosus crude biosurfactant (B,D,F,H). 


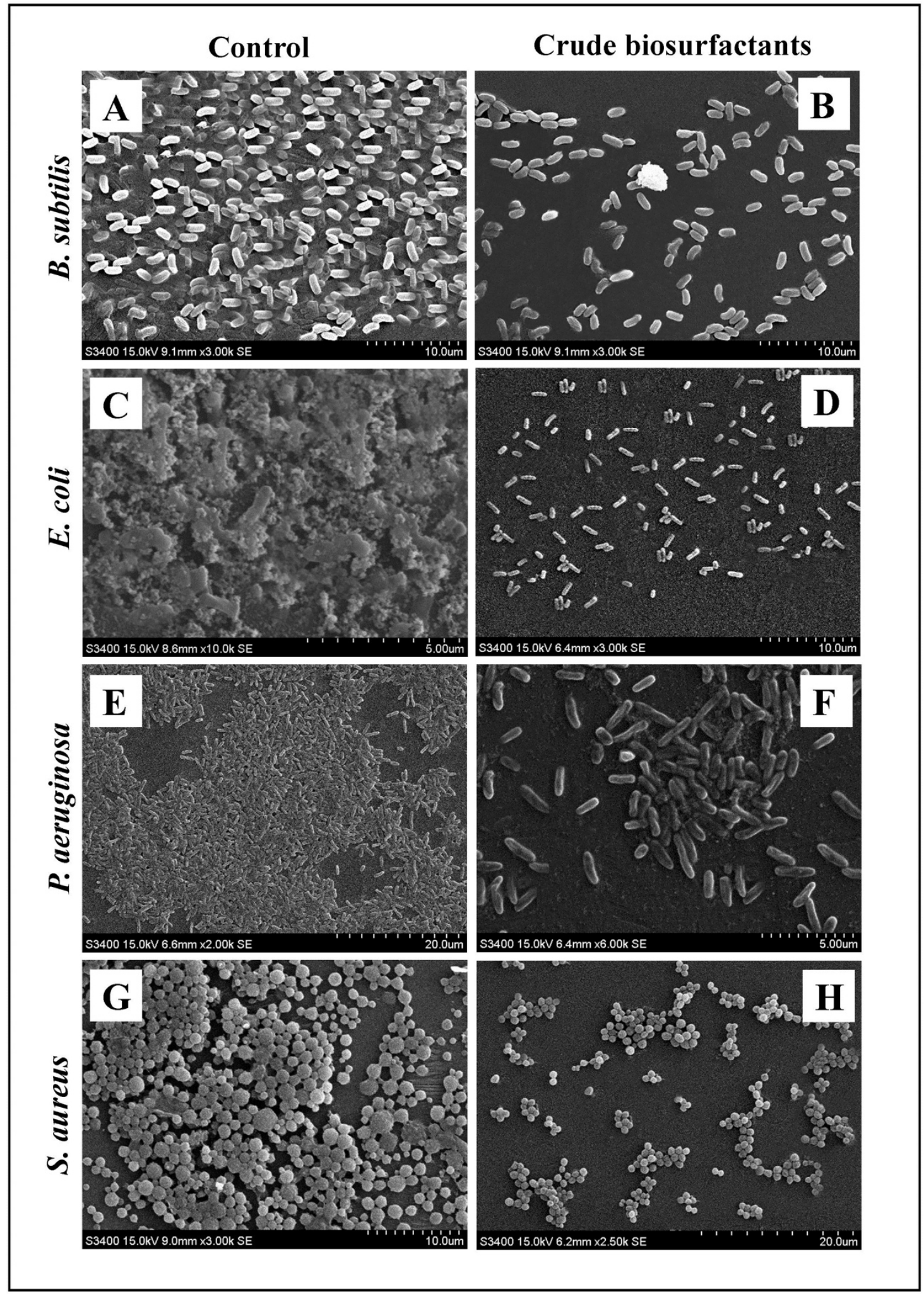

Figure 7. Micrographs of the disrupted matured biofilms of the test pathogens by the L. rhamnosus crude biosurfactant formed on a glass surface at their respective MICs under SEM. Growth control (A,C,E,G); with the L. rhamnosus crude biosurfactant (B,D,F,H). 


\subsection{Gas Chromatography-Mass Spectrometry (GC-MS) Analysis}

The analytical technique GC-MS consists of gas chromatography combined with mass spectroscopy for the detection of various compounds present in the sample. The GC-MS chromatogram of the L. rhamnosus crude biosurfactant shows different peaks, indicating the presence of different compounds (Figure 8). Major peak compounds at the respective retention time were identified from the standard library compound, and are shown in Table 3.

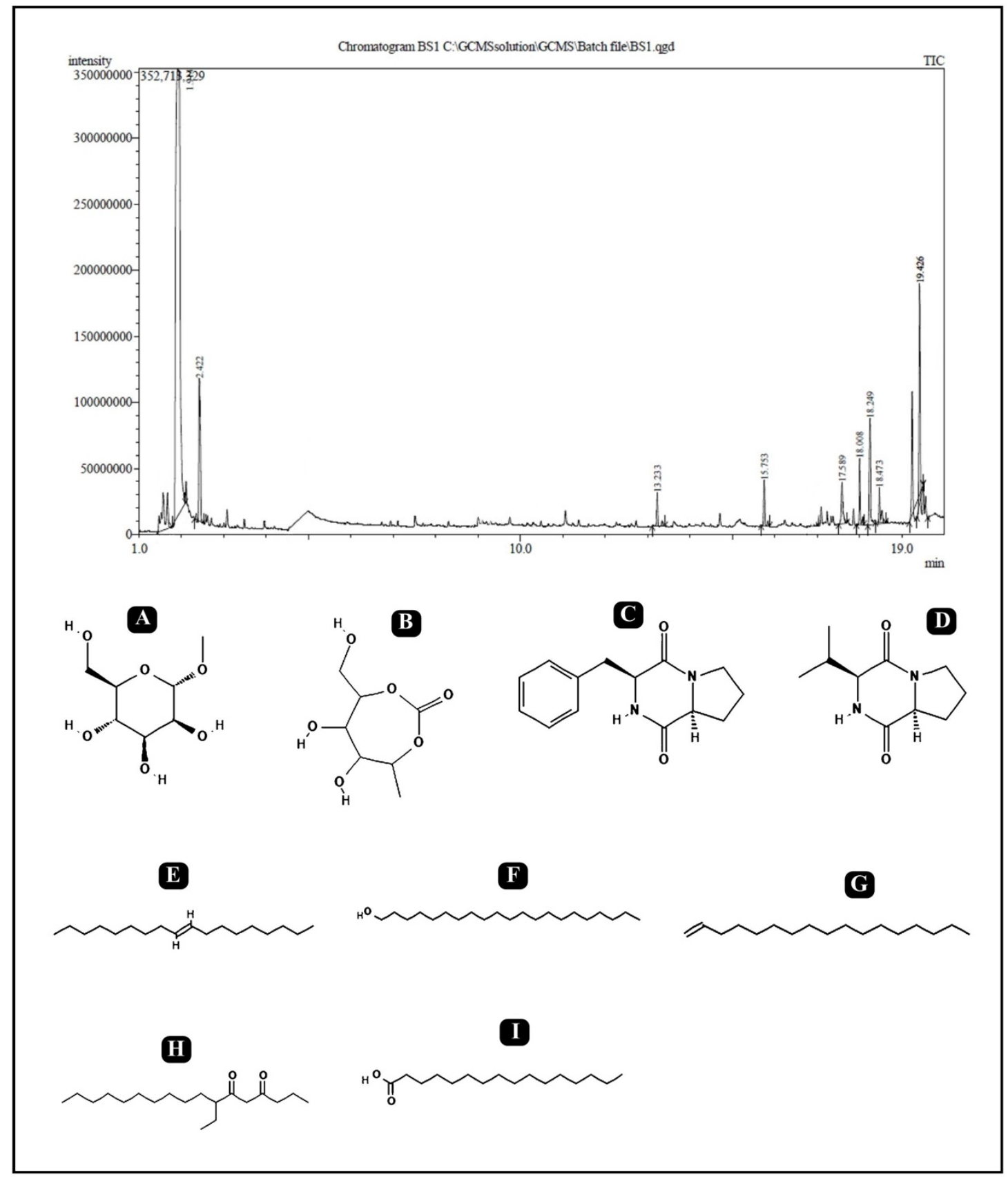

Figure 8. GC-MS analysis of the crude biosurfactants derived from L. rhamnosus. Identified compounds: (A) Isopropyl alpha-D-mannopyranoside; (B) 2,5-Monomethylene-l-rhamnitol; (C) (Cyclo(Phe-Pro)); (D) Cyclo(L-prolyl-L-valine); (E) 9Octadecene; (F) 1-Heneicosanol; (G) 1-Heptadecene; (H) 7-Ethyl-4,6-heptadecandione; (I) n-Hexadecanoic acid. 
Table 3. Major constituents of the crude biosurfactants of L. rhamnosus using GC-MS.

\begin{tabular}{|c|c|c|c|c|}
\hline No. & RT & $\%$ Area & Compound Name & Class \\
\hline 1 & 1.914 & 47.87 & Isopropyl alpha-D-mannopyranoside & Glycoside \\
\hline 2 & 2.422 & 4.98 & 2,5-Monomethylene-l-rhamnitol & Sugar Alcohol \\
\hline 3 & 13.233 & 0.92 & 9-Octadecene, (E)- & Fatty Acyl \\
\hline 4 & 15.753 & 1.13 & 1-Heptadecene & Fatty Acyl \\
\hline 5 & 17.589 & 1.51 & $\begin{array}{l}\text { Pyrrolo[1,2-a]pyrazine-1,4-dione,hexahydro-3- } \\
\text { (phenylmethyl)- } \\
\text { Cyclo (D-phenylalanyl-L-prolyl) (Cyclo(Phe-Pro)) }\end{array}$ & Dipeptide \\
\hline 6 & 18.008 & 1.71 & 1-Heneicosanol & Fatty alcohol \\
\hline 7 & 18.249 & 4.86 & Cyclo(L-prolyl-L-valine) & $\begin{array}{c}\text { Diketopiperazine } \\
\text { (Dipeptide) }\end{array}$ \\
\hline 8 & 18.473 & 1.10 & 7-Ethyl-4,6-heptadecandione & Fatty Acyl \\
\hline 9 & 19.426 & 4.15 & $n$-Hexadecanoic acid & Surfactant \\
\hline
\end{tabular}

\section{Discussion}

Biofilm can be developed on any kind of biotic and abiotic materials. In liquid medium, it floats on the surfaces and can be in a submerged state. The majority of human diseases are mainly caused by pathogenic bacteria such as E. coli, S. aureus, S. epidermis, P. aeruginosa, etc., which are biofilm associated. The diseases caused by/related to biofilm increases the patient morbidity and rate of mortality, leading to a significant economic burden. Within biofilm, bacteria adopt numerous resistant characteristics, which makes them difficult to remove. Moreover, due to the formation of biofilm, the effectiveness of antimicrobial agents is reduced, and the majority of the pathogenic bacteria are no longer susceptible to the available therapeutic agents and antibiotics [1]. Therefore, biofilm formation is a major global concern in current times, which demands novel strategies/alternatives/approaches to control or inhibit biofilm formation.

For infants, the breast milk of humans is recognized as a prime food as it contains all the required nutritional content. Additionally, it provides immunity and gives out to several degrees of protection against infectious diseases [36]. This is due to the presence of diverse types of bioactive molecules (antimicrobial compounds, immune cells and immunoglobulins) that are produced by the microbiota present within the breast milk [37,38]. Several bacterial species, such as Bifidobacteria, Enterococci, Lactobacilli, Lactococci, Micrococci, Staphylococci and Streptococci, are reported from human breast milk [39]. Although, there is limited knowledge about the probiotic bacteria and their constituents involved in maintaining the health of the lactating mother and newborn baby. In the present study, the probiotic lactic acid bacterial strain L. rhamnosus was isolated from human breast milk, screened, and the functional and biomedical potential of the biosurfactant synthesized by it was characterized.

Biosurfactants have broad applications in food, oil, biodegradation, cosmetic, agriculture, pesticide and medicine/pharmaceutical industries, because of their special properties such as environmentally friendly nature, high selectivity and precise mode of action under harsh environment conditions, such as temperature, $\mathrm{pH}$ and salinity [40,41]. Biosurfactants are also reported for their potent antibacterial activity against certain pathogenic bacteria and their biofilms [42]. Biosurfactants cause the formation of pores and ion channels in lipid bilayer membranes, which disrupts the integrity and porosity of the membranes. This leads to membrane disruption and cell death. As a result of this mechanism of action, biosurfactants are active in a range of biological activities, including antibacterial, antifungal, antiviral and antimycoplasma $[43,44]$. Their biological activity is determined by the structures of these molecules. A lipopeptide may form micellular aggregates or pore channels in the lipid membrane, causing membrane disruption, increased membrane 
permeability, increased metabolites leakage, membrane structure change, protein conformation change, altering membrane functions and cell death. The dimerization of surfactin into the membrane bilayer causes membrane leakage and instability. Rhamonolipids reduce the lipopolysaccharide content in membranes, increase cell hydrophobicity, alter membrane proteins and disturb surface morphology. Additionally, biosurfactants aid in the detachment of microbial cells from surfaces through sloughing, erosion and abrasion [45]. Furthermore, biosurfactants regulate the quorum sensing signaling (intercellular and intracellular communication) and quorum sensing-dependent activities, such as biofilm formation, motility and pathogenicity, are influenced by this saignaling. Upon binding with ATPase on the mitochondrial membrane, biosurfactants cause apoptosis in several microbial cells cells at low concentrations [46,47]. In the literature, few strains of LAB are reported for their biosurfactant production ability and antimicrobial potential and inhibition of biofilm formation of many pathogenic microorganisms [27,48-51]. The biosurfactants derived from different probiotic LAB has extensive applications in these fields. Therefore, assessment of biofilm development prevention or disruption by biosurfactants derived from probiotic L. rhamnosus might be a plausible approach that can lead to the discovery of novel antimicrobials.

The biosurfactant production ability of L. rhamnosus was tested via different qualitative and quantitative methods, such as drop collapse, oil displacement, C-TAB agar plate and emulsification. All these methods are easy to perform and effective to confirm the production of distinct types of biosurfactants from bacteria [52]. The biological surfactants produced by different microbes have advantages over the chemical surfactants, such as biodegradability, low toxicity and environment suitability, which becomes greatly advantageous in different applications. The biosurfactant production from L. rhamnosus was started during the log phase and found to be growth dependent. In the stationary phase, the maximum reduction in surface tension $(42.48 \pm 1.22 \mathrm{mN} / \mathrm{m})$, cell biomass $(4.84 \pm 0.12 \mathrm{~g} / \mathrm{L})$ and production of biosurfactant $(4.32 \pm 0.19 \mathrm{~g} / \mathrm{L})$ was found. The production of biosurfactant and reduction in the value of surface tension were found to be constant till the end of the stationary growth phase (Figure 1). The same kind of pattern in the reduction of surface tension is reported in other studies from LAB strains. Rodrigues et al. (2004) reported the reduction of surface tension from 72 to $39 \mathrm{mN} / \mathrm{m}$ and 72 to $37 \mathrm{mN} / \mathrm{m}$, while working with Lactobacillus fermentum RC-14 and Streptococcus thermophilus A, respectively [28].

One more important parameter of a biosurfactant is the formation of micelles, which is known as the aggregation of amphipathic molecules [16,53,54], and which is necessary to classify an efficient and effective biosurfactant for use and application. The effectiveness is determined from the lowest value at which a reduction in surface tension occurs, whereas $\mathrm{CMC}$ is analyzed for the determination of efficiency [55]. Once the concentration of the surfactant is increased in the medium, a reduction in surface tension is started and formation of micelles occurred. The CMC value of the biosurfactant produced by $L$. rhamnosus was found to be $3.0 \mathrm{~g} / \mathrm{L}$. The commonly used chemical surfactant SDS has a $\mathrm{CMC}$ value of $1.8 \mathrm{~g} / \mathrm{L}$, which reduces the surface tension from 72.0 to $37 \mathrm{mN} / \mathrm{m}[48,56,57]$. The CMC value of the biosurfactant produced by Lactobacillus delbrueckii in peanut oil cake was around $2 \mathrm{~g} / \mathrm{L}$ [22]. The effectiveness of any kind of surfactant was determined via its capacity to reduce the surface and interfacial tension of the production medium. Hence, the biosurfactant derived from L. rhamnosus is efficient, which can lower the surface tension from $71.12 \pm 0.73 \mathrm{mN} / \mathrm{m}$ to $41.76 \pm 0.60 \mathrm{mN} / \mathrm{m}$. Thus, the results of the present study are in accordance with the other studies in which biosurfactants are extracted from other LAB.

Biosurfactants can alter the necessary functions of the bacterial cell membrane, which are required for the pathogenicity by causing a disruption in the cytoplasmic membranes, which sequentially leads to cell lysis, leakage of important metabolites and disturbs the protein confirmation $[58,59]$. In the present study, the crude biosurfactant of L. rhamnosus was found effective against both Gram-positive and Gram-negative bacteria at different levels. The MIC and MBC values are admirable and relatively economical methods to simultaneously determine the efficacy of the different antimicrobial compounds. The MIC 
value represent the minimum concentration of the antimicrobial compound that significantly inhibits the growth of bacteria, whereas $\mathrm{MBC}$ represent the minimum concentration of any antimicrobial compound that carried out the death of the microbial cell. Generally, antibacterial compounds are recognized as bactericidal, if their $\mathrm{MBC}$ values are not more than four times the MIC [60]. According to the obtained MIC values, B. subtilis, E. coli, P. aeruginosa and S. aureus were susceptible to the crude biosurfactant of L. rhamnosus. The values of MIC and MBC was about 12.5 and $25 \mathrm{mg} / \mathrm{mL}$ for B. subtilis and E. coli, 25 and $50 \mathrm{mg} / \mathrm{mL}$ for $P$. aeruginosa, and 50 and $1000 \mathrm{mg} / \mathrm{mL}$ for $S$. aureus. The obtained results displayed the bactericidal potential of the crude biosurfactant of L. rhamnosus.

Apart from antibacterial potential, the L. rhamnosus-derived biosurfactant also showed significant results in inhibiting the biofilms of the test pathogens at their respective MICs in a concentration-dependent manner. The L. rhamnosus-derived biosurfactant was found to be effectively hampering the adhesion ability, as well as impeding the preformed biofilms of the test strains (Figure 3B,C). The results of the XTT assay also verified that the bacterial cells within the biofilms was inhibited by the crude biosurfactant of L. rhamnosus (Figure 4A). The obtained results provided the evidence that the L. rhamnosus-derived biosurfactant could also affect the integrity of bacterial cells inside the biofilm. Moreover, the crude biosurfactant also impaired bacterial cells, possibly releasing the intrinsic intracellular enzyme LDH (Figure 4B).

The biomass of biofilm of the pathogenic bacteria was determined via the standard crystal violet method. The results of the present study displayed that the L. rhamnosusderived biosurfactant was efficient in inhibiting the biofilms (Figure 5). This result was further verified by visualizing the biofilms under SEM (Figure 6). Disrupted integrity of the cell walls, and a reduction in the thickness of the multi-layered biofilm growth can be seen. Furthermore, in the presence of a crude biosurfactant of L. rhamnosus, all bacterial strains failed to develop as clusters, as well as were unable to maintain their typical morphology. This is due to the compromised cell walls. One more essential studied aspect was EPS, which is produced by the bacteria and is vital for not only maintaining the structural integrity, but also substantially contributing to adhesion to various surfaces and microcolony development, leading to the formation of biofilms [61]. Our study displayed remarkable results in inhibiting the EPSs of all the test strains by the crude biosurfactant of L. rhamnosus. An EPS-rich matrix is very crucial for maintaining the physical stability and attachment of biofilms [62]. Therefore, targeting the biochemical constitution of EPS ultimately destabilizes the biofilm matrix and its complexity, which further eases the drug access directly into the biofilms [63].

The antibiofilm and anti-adhesion ability of the LAB-derived biosurfactants has been reported towards various microbial pathogens $[23,27,59,64-67]$. Therefore, studying the antibiofilm and anti-adhesion potential of LAB-derived biosurfactants might be considered as important to understand the mechanism behind it and identifying the potent chemical constituents in the crude biosurfactant responsible for combating the colonization of pathogenic microbes on different type of surfaces [65,68]. Sambanthamoorthy et al. (2014) extracted cell-bound biosurfactants from the L. rhamnosus 7469 strain and reported its antimicrobial, anti-adhesive and antibiofilm activities against $A$. baumannii, E. coli and $S$. aureus [69]. The biosurfactant derived from L. helveticus MRTL91 had lower anti-adhesive activity against $S$. typhi, E. coli, P. aeruginosa, S. flexneri and C. albicans at the same concentration. Falagas and Makris (2009) reported the anti-adhesion potential of biosurfactants isolated from the probiotic microorganism against the colonization of pathogens onto medical equipment/implants to control the nosocomial infections in hospitals [25]. Rodrigues et al. (2006) reported the application of an S. thermophilus-derived biosurfactant to inhibit the colonization of microbial pathogens on silicone rubber [27]. Gudina et al. (2010) reported the anti-adhesive ability of LAB-derived biosurfactants, and among those, the highest anti-adhesive activity was found against S. aureus, S. epidermidis and S. agalactiae at a concentration of $25 \mathrm{mg} / \mathrm{mL}$ [70]. The antibiofilm potentiality of the biosurfactants derived from two LAB strains, L. paracasei and L. paracasei ssp. paracasei A20, has been 
also reported against yeast and several human bacterial pathogens, and about $75 \%$ inhibition was found. Fracchia et al. (2010) also reported an 85\% inhibition of biofilm at a biosurfactant concentration of $312.5 \mu \mathrm{g} / \mathrm{mL}$ derived from Lactobacillus spp. [71]. The complete inhibition of biofilm was found for a silicone tube at a concentration of $25 \mathrm{mg} / \mathrm{mL}$ of a biosurfactant derived from L. helveticus MRTL 91 [27]. More than $50 \%$ of the biofilm inhibition of different bacterial pathogens, such as E. coli, S. aurues, C. albicans, E. faecalis and $S$. epidermidis, has been reported by biosurfactants derived from L. acidophilus. The biosurfactants derived from L. fermentum B54 also showed anti-adhesive activity against uropathogenic microorganisms [54,62]. A few more strains of LAB, which are able to produce biosurfactants, are also reported to decrease the biofilm formation of several pathogens $[27,64,72]$. Biosurfactants derived from L. lactis 53 also inhibit the growth of $R$. cariosa and C. tropicalis on silicone tubing.

Moreover, bioactive compounds known to have antibacterial and antibiofilm potential present within the crude biosurfactants of L. rhamnosus were identified via GC-MS analysis (Table 3). From the identified bioactive compounds, Pyrrolo[1,2-a]pyrazine-1,4dione,hexahydro-3-(phenylmethyl)-Cyclo(D-phenylalanyl-L-prolyl) is well-known for its potent inhibitory effect on multidrug-resistant $S$. aureus and other pathogenic bacteria [73]. Mannofuranoside and its derivatives are also reported as strong antimicrobial agents, specifically against pathogenic fungi and several pathogenic Gram-positive and Gram-negative bacteria [74]. 1-Heneicosanol is known for its antibacterial and antifungal activities [75] as well as for its anti-tuberculosis activity [76]. Identified 9-Octadecene, (E)-, 1-Heptadecene, $n$-Hexadecanoic acid are non-polar components, which are reported for their efficient antimicrobial activity against different pathogenic bacteria, such as E. coli, P. aeruginosa, $B$. subtilis, S. aueus, E. faecalis, S. pneumoniae, P. mirabilis and a fungus/yeast (C. albicans) [77-79]. Cyclo(L-prolyl-L-valine) is a cyclic dipeptide known as Diketopiperazines. It has been reported to be produced from different microbial species and is known to possess antitumor, antiviral, antifungal, antibacterial, anti-prion and anti-hyperglycemic activities [80].

\section{Materials and Methods}

\subsection{Isolation and Screening of Lactic Acid Bacteria}

Isolation of probiotic LAB was carried out from human breast milk. The sample was transferred in a flask consisting de Man, Rogosa and Sharpe (MRS) broth (Hi-Media ${ }^{\circledR}$, Mumbai, India) (100 mL) as enrichment media and incubated at $37^{\circ} \mathrm{C}$ for $24 \mathrm{~h}$. After the incubation period, $100 \mu \mathrm{L}$ of the enriched sample was spread on MRS agar plates with incubation in anaerobic conditions for $48 \mathrm{~h}$ at $37^{\circ} \mathrm{C}$. Subsequently, purified bacterial colonies were sub-cultured. The purified bacterial colonies were maintained on an MRS agar medium for immediate use and stored at $-20{ }^{\circ} \mathrm{C}$ in $20 \%$ glycerol for future use.

\subsection{Identification of Lactic Acid Bacteria}

Identification of isolated lactic acid bacterial strain was carried out via the 16S rRNA gene sequencing method. Genomic DNA was extracted using bacterial genomic DNA kit (GenElute $^{\mathrm{TM}}$, Sigma-Aldrich, Bangalore, India). Quantification was carried out according to the method described by Sambrook et al. (1982) [81]. Optical density (OD) was measured (UV-1800, Shimadzu Spectrophotometer, Tokyo, Japan) at 260 and $290 \mathrm{~nm}$. Further, 0.8\% agarose gel was used to confirm the purity of the extracted genomic DNA by electrophoresis. 16S rRNA gene amplification was carried out by using a pair of universal primers $27 \mathrm{f}$ (5'AGAGTTTGATCCTGGCTCAG3') and 1492r (5'CGGTTACCTTGTTACGACTT3'). A final volume of $20 \mu \mathrm{L}$ was used for the PCR amplification containing 10 pmol of each primer, $1 \times$ ReadyMix $^{\mathrm{TM}}$ Taq PCR reaction mix (Sigma-Aldrich ${ }^{\circledR}$, Bangalore, India) and $\sim 50 \mathrm{ng}$ of template DNA, and to make up the total volume, nuclease-free water was added. The PCR cycling conditions were: $95^{\circ} \mathrm{C}$ for $4 \mathrm{~min}, 35$ cycles of $95^{\circ} \mathrm{C}$ for the $30 \mathrm{~s}, 54{ }^{\circ} \mathrm{C}$ for $30 \mathrm{~s}$, and $72{ }^{\circ} \mathrm{C}$ for $1 \mathrm{~min}$, followed by a final extension step at $72{ }^{\circ} \mathrm{C}$ for $5 \mathrm{~min}$ with a hold at $-4{ }^{\circ} \mathrm{C}$ for $\infty$ time in a Thermal cycler (Applied Biosystems Veriti ${ }^{\circledR}$, Lenexa, KS, USA). 1\% agarose gel was used to detect the amplified PCR products by electrophoresis. 
Staining was performed by ethidium bromide (EtBr), followed by visualization under UV light. Further purification of the amplified PCR product was done using the GenElute ${ }^{\mathrm{TM}}$ PCR Clean-up kit (Sigma-Aldrich ${ }^{\circledR}$, Bangalore, India) and the purified PCR product was sequenced. Finally, the Basic Local Alignment Search Tool (BLAST) on NCBI was used to carry out the sequence match analysis and sequences were later submitted to GenBank.

\subsection{Biosurfactant Assays}

Firstly, the isolated LAB strains were screened for its qualitative biosurfactant production ability via the following different assays.

\subsubsection{Emulsification Assay}

The potentiality of the biosurfactants to emulsify n-hexadecane was carried out via an emulsification test [82]. Equal volumes of n-hexadecane and a cell-free biosurfactant solution were mixed by vortexing for $2 \mathrm{~min}$ and left to stand for $24 \mathrm{~h}$. Calculation of an emulsification index (\% EI24) was done by using the following equation:

$$
\% \text { EI24 }=\frac{\text { Height of formed emulsion }}{\text { Total height of the solution }} \times 100
$$

\subsubsection{Drop-Collapse Assay}

The method described by Plaza et al. (2006) was followed to perform the drop-collapse test [83]. Firstly, a drop $(35 \mu \mathrm{L})$ of cell-free biosurfactant solution was put onto parafilm for observation of drop spreading on the parafilm surface after $15 \mathrm{~min}$. The collapsed drop was scored as a positive result, which indicated the presence of biosurfactants.

\subsubsection{Oil-Spreading Assay}

The method described by Joe et al. (2019) was followed to perform the oil-spreading assay [84]. Firstly, distilled water $(50 \mathrm{~mL})$ was added to the Petri plates, followed by vegetable oil $(100 \mu \mathrm{L})$ on the surface of the water. Later, on to the oil surface, $10 \mu \mathrm{L}$ of the cell-free biosurfactant solution was put. After $30 \mathrm{~s}$, the surface of the oil was visualized for the development of a clear zone.

\subsubsection{Blue Agar Plate (BAP) Assay}

A BAP assay was carried out for the detection of biosurfactants on a minimal agar medium consisting of cetyl trimethyl ammonium bromide (C-TAB, $0.4 \mathrm{mg} / \mathrm{mL}$ ), glucose $(2 \%)$ and methylene blue dye $(0.2 \mathrm{mg} / \mathrm{mL})$. Wells of $6 \mathrm{~mm}$ in size were made into the plates with the help of a sterile cork borer and $20 \mu \mathrm{L}$ of a cell-free biosurfactant solution was added into the wells. Plates were left in a refrigerator for $30 \mathrm{~min}$ for the diffusion of the spent broth and kept for incubation for $24 \mathrm{~h}$ at $37^{\circ} \mathrm{C}$. After the incubation period, the presence of a dark blue color halo around the wells were observed in the plates.

\subsection{Surface Tension Measurements}

The surface tension was measured with a tensiometer (K11, Krus, Germany). Pure water was used as a standard before reading $(72.50 \mathrm{mN} / \mathrm{m})$.

\subsection{Control Solutions}

In the screening assays, phosphate-buffered saline (PBS) was used as a negative control and sodium dodecyl sulphate (SDS) was used as a positive control.

\subsection{Production of Biosurfactant and Extraction}

The production of biosurfactants by the isolated LAB strain was carried out via growing them in MRS-Lac broth (cultivation medium for LAB, where glucose is substituted by lactose). For the production of the crude biosurfactant, an overnight grown culture of L. rhamnosus $(1 \%)$ was inoculated in MRS-Lac $(1000 \mathrm{~mL})$ medium and incubated at $37^{\circ} \mathrm{C}$ 
for $48 \mathrm{~h}$ without shaking. After the incubation period, a culture medium was placed for centrifugation $\left(10,000 \mathrm{rpm}, 10 \mathrm{~min}, 10^{\circ} \mathrm{C}\right)$ to harvest the cells. Next, demineralized water was used to wash the cells twice and further re-suspended in $100 \mathrm{~mL}$ of phosphate-buffered saline (PBS) $(\mathrm{pH}=7.0)$. This solution was stirred gently at room temperature for $4 \mathrm{~h}$ to release the cell-associated biosurfactant. After $4 \mathrm{~h}$, centrifugation was carried out to remove the bacteria and the supernatant was collected by filtering with $0.22 \mu \mathrm{m}$ filter. In the end, the filtered and sterilized supernatant was lyophilized, stored at $-40{ }^{\circ} \mathrm{C}$ and further resuspended in deionized water at $100 \mathrm{mg} / \mathrm{mL}$. This solution of the crude biosurfactant was then used for the biosurfactant assay and biofilm eradication assay.

\subsection{Assessment of Biomass and Biosurfactant Concentration}

Growth of the bacteria was investigated by taking the OD of the broth at $600 \mathrm{~nm}$. For the determination of biomass, a regular method for the measurement of cell dry weight was employed. A total $10 \mathrm{~mL}$ of the bacterial sample was transferred into pre-weighed tubes and centrifuged at 10,000 rpm for $10 \mathrm{~min}$. Lastly, the cell pellet was collected and ovendried for $24 \mathrm{~h}$ at $100^{\circ} \mathrm{C}$ and the dry weight was estimated eventually. The biosurfactant concentration was determined according to the procedure described above (Section 4.6) and the concentration of the produced biosurfactant was represented in $\mathrm{mg} / \mathrm{mL}$.

\subsection{Assessment of Physical Properties of Biosurfactant}

To investigate the \%EI24 of the produced biosurfactant by L. rhamnosus, an equal volume of n-hexadecane and biosurfactant solution was mixed for 2 min vortexing and left to stand for $24 \mathrm{~h}$. Then, calculation of an emulsification index (\%EI24) was carried out as described above. Beside from n-hexadecane, the \%EI24 of the produced biosurfactant was also investigated against various substrates such as gasoline, diesel, kerosene, toluene, olive oil and sunflower oil. Further, using a surface tensiometer, values of CMC and ST reduction were evaluated. CMC is defined as the abrupt discontinuity in the surface tension plot versus the plot of biosurfactant concentration.

\subsection{Assessment of Antibacterial Activity}

All pathogenic bacterial strains, B. subtilis (MTCC 121), P. aeruginosa (MTCC 741), S. aureus (MTCC 96) and E. coli (MTCC 9537), were obtained from the Microbial Type Culture Collection (MTCC), India, and maintained on Muller-Hinton Agar (MHA). The antibacterial activity of the L. rhamnosus crude biosurfactant and standard SDS was carried out via the agar cup/well diffusion method. Firstly, bacterial cultures were grown overnight at $37^{\circ} \mathrm{C}$ in a fresh medium and a total of $0.5 \mathrm{Mc}$ Farland standard $10^{8}$ colony-forming units $/ \mathrm{mL}(\mathrm{CFU} / \mathrm{mL})$ was matched by culture turbidity adjustment using a sterile saline solution. The bacterial suspension was evenly spread all over the plates and wells were made with a sterile cork borer. A total of $60 \mu \mathrm{L}$ of the biosurfactant solution $(100 \mathrm{mg} / \mathrm{mL})$ and SDS $(1 \% v / v)$ solution was then inoculated into each respective well and plates were incubated at $37^{\circ} \mathrm{C}$ for $24 \mathrm{~h}$. Antibacterial activity was noted in the form of zone of inhibition. Chloramphenicol and sterile water were used as the positive and negative control, respectively.

\subsection{Minimum Inhibitory Concentration (MIC) and Minimum Bactericidal Concentration $(M B C)$ Determination}

MIC determination of the L. rhamnosus crude biosurfactant and standard SDS was carried out in microtiter plates (96-well) against the tested bacterial strains, as reported previously [85]. The inoculums were prepared from $12 \mathrm{~h}$ Muller-Hinton broth (MHB) culture. The L. rhamnosus crude biosurfactant was diluted to two-fold ranging from 100 to $1.56 \mathrm{mg} / \mathrm{mL}$ in MHB in a 96-well plate (100 $\mu \mathrm{L}$ each well). Similarly, standard SDS was also diluted (1 to $0.2 \%$ ). A diluted culture of each test bacteria was added to the respective well to control the final concentration of $10^{8} \mathrm{CFU} / \mathrm{mL}$, followed by being incubated for $24 \mathrm{~h}$ at $37^{\circ} \mathrm{C}$. The MIC was then recorded as the lowest concentration at which absolute inhibition of observable growth occurred. Wells with media were used as a negative control, 
whereas wells without biosurfactant in media but only inoculated bacteria were used as a positive control. Similar to the MIC assay, MBC determination of the L. rhamnosus crude biosurfactant was also carried out by spreading $5 \mu \mathrm{L}$ of sample from the wells, which exhibited no evident growth on MHA plates, and kept for incubation for $24 \mathrm{~h}$ at $37^{\circ} \mathrm{C}$. The $\mathrm{MBC}$ was recorded as the lowest concentration at which $99 \%$ of the inoculum was killed; i.e., three or fewer colonies [86].

\subsection{Preparation of Biofilm}

The crystal violet (CV) method was followed for determining the biofilm-forming ability of the tested strains using 96-well polystyrene plates [87]. Briefly, a log-phase culture of each test strain with MHB $(200 \mu \mathrm{L})$ at an initial turbidity of 0.05 at $600 \mathrm{~nm}$ was incubated for $24 \mathrm{~h}$ at $37{ }^{\circ} \mathrm{C}$ without shaking. After the incubation period, planktonic cells were removed by washing thrice with PBS and air-dried. A $0.1 \% \mathrm{CV}$ was then used for staining the wells and kept for 20 min. By dissolving in 95\% ethanol, the excess amount of dye was taken out and absorbance was measured at $570 \mathrm{~nm}$.

\subsection{Antibiofilm Assays}

4.12.1. Effect of the L. rhamnosus Crude Biosurfactant on the Established Biofilms

The method described by Lemos et al. (2018) was followed to assess the efficacy of the L. rhamnosus crude biosurfactant and standard SDS on established biofilms. 96-well microtiter plates were used to form the biofilms by test strains containing $1 \%$ glucose, $\mathrm{MHB}$ and cells $\left(10^{7}\right.$ cells $\left./ \mathrm{mL}\right)$ [60]. Plates were incubated for $24 \mathrm{~h}$ at $37^{\circ} \mathrm{C}$. After incubation, planktonic cells were delicately removed from the wells with further washing of the wells with saline thrice. After washing, the L. rhamnosus crude biosurfactant and standard SDS (MIC) $(200 \mu \mathrm{L})$ were added to the respective wells and plates were kept for another day $(24 \mathrm{~h})$ of incubation at $37^{\circ} \mathrm{C}$. Absorbance $(492 \mathrm{~nm})$ was measured at 0 and after $24 \mathrm{~h}$. The MHB medium without any surfactant and with individual test strain was used as the biofilm growth control and the biofilm eradication percentage was calculated as

$$
[(\mathrm{OD} \text { (control) }-\mathrm{OD} \text { (test) } / \mathrm{OD}(\text { control) }] \times 100
$$

\subsubsection{Effect of the L. rhamnosus Crude Biosurfactant on Adherence of Biofilms}

The method described by Plyuta et al. (2013) was followed to determine the effect of the L. rhamnosus crude biosurfactant and standard SDS on the adherence of biofilms formation [88]. The bacterial cell culture $(100 \mu \mathrm{L})$ of each tested strain $\left(10^{8} \mathrm{CFU} / \mathrm{mL}\right)$ and $L$. rhamnosus crude biosurfactant and standard SDS (MIC) collectively in the respective 96-well microtiter plates were incubated for $24 \mathrm{~h}$ at $37^{\circ} \mathrm{C}$. After incubation, planktonic cells were delicately removed from the wells with further washing of the wells with PBS $(200 \mu \mathrm{L})$. After washing, the adhered cells were stained with $0.1 \% \mathrm{CV}$ for a 30 min incubation at $37{ }^{\circ} \mathrm{C}$ to visualize the developed biofilms by test strains. Excess $\mathrm{CV}$ dye was washed off with PBS and plates were finally fixed using 95\% ethanol $(200 \mu \mathrm{L})$ and incubation for $15 \mathrm{~min}$ at $37^{\circ} \mathrm{C}$. Absorbance at $590 \mathrm{~nm}$ was then measured. Inhibition percentage was calculated as

$$
[(\mathrm{OD} \text { (control) }-\mathrm{OD} \text { (test) } / \mathrm{OD} \text { control) }] \times 100
$$

\subsection{Microscopic Assessment}

\subsubsection{Determining and Visualization of Antibiofilm Activity by Light Microscopy}

The method described by Musthafa et al. (2010) was followed to investigate the biofilms formed by the test strains using LM with slight modifications [89]. 24-well microtiter plates consisting of $1 \times 1 \mathrm{~cm}$ size cover slips were inoculated with $500 \mu \mathrm{L}$ of the test cultures $\left(10^{8} \mathrm{CFU} / \mathrm{mL}\right)$. In the same well, $500 \mu \mathrm{L}$ of the L. rhamnosus crude biosurfactant (final concentration = MIC) was added as the treatment. For the positive control, the same volume of chloramphenicol was used with the test strains. For the negative control, the same volume of sterile water was used with the tested strains. After the incubation period 
of $24 \mathrm{~h}$ at $37{ }^{\circ} \mathrm{C}$, glass cover slips with the formed biofilms were gently removed and washed with PBS. Staining was performed with $0.1 \% \mathrm{CV}$ as described above, followed by washing and air-drying for $5 \mathrm{~min}$. Cover slips stained with $\mathrm{CV}$ were then observed under LM with 40× magnification (Axioscope A1, ZEISS, Oberkochen, Germany).

\subsubsection{Determination and Visualization of Antibiofilm Activity by Scanning Electron Microscopy}

All the tested strains' biofilms were also analyzed by SEM (with and without the L. rhamnosus crude biosurfactant as well as the respective controls as described above). First, the biofilms were fixed on glass coverslips using $2.5 \%$ glutaraldehyde at $37^{\circ} \mathrm{C}$ for $30 \mathrm{~min}$. After fixing, cover slips were washed thrice with PBS and then dehydrated through a graded series of ethanol solution (30\%,50\%,70\%, 90\% and 100\%) at 15 min intervals. Samples were then freeze dried after reinstation of ethanol with isoamyl acetate. Finally, using E-1010 ion sputter (Hitachi ${ }^{\circledR}$, Tokyo, Japan), cover slips were coated with gold and observed under SEM (S-34002N SEM, Hitachi ${ }^{\circledR}$, Japan).

\subsection{Bacterial Metabolic Activity in the Biofilm Assays}

To determine the viability of the bacterial cells within the biofilms a colorimetric XTT reduction test was performed [66,90,91]. Briefly, a log phase culture of each test strain collectively in MHB $(200 \mu \mathrm{L})$ with and without the L. rhamnosus crude biosurfactant at an initial turbidity of 0.1 at $600 \mathrm{~nm}$ was incubated for $24 \mathrm{~h}$ at $37^{\circ} \mathrm{C}$ without shaking. After the incubation period, planktonic cells were removed by washing thrice with distilled water, followed by sterile PBS $(100 \mu \mathrm{L})$. After washing, the XTT-menadione $(100 \mu \mathrm{L})$ solution (freshly prepared) was added into the wells. Plates were then incubated in the dark at $37^{\circ} \mathrm{C}$ for $5 \mathrm{~h}$. Following the incubation, a colored supernatant $(100 \mu \mathrm{L})$ was transferred from each well to a new 96-well microtiter plate. A microplate reader was then used to record the absorbance at $480 \mathrm{~nm}$. The survival percentage of the bacterial population was determined as follows:

[(OD (biosurfactant treated sample) - OD (negative control) /OD of untreated control) $] \times 100$

\subsection{Bacterial Cell Damage Assay}

To determine the damage to bacterial cells within the biofilms, an LDH assay was carried out. Briefly, the $\log$ phase culture of each test strain $(100 \mu \mathrm{L})$ with $\mathrm{MHB}(100 \mu \mathrm{L})$ was added into 96-well microtiter plates and incubated for $24 \mathrm{~h}$ at $37^{\circ} \mathrm{C}$ under static condition. After the incubation period, planktonic cells were discarded by washing thrice with sterile PBS $(100 \mu \mathrm{L})$. The L. rhamnosus crude biosurfactant (MIC) $(100 \mu \mathrm{L})$ was then added and the plates were kept for further incubation at $37^{\circ} \mathrm{C}$ for $24 \mathrm{~h}$ under static conditions. After incubation, the LDH activity was then determined by collecting the supernatant using an LDH assay kit (Sigma-Aldrich ${ }^{\circledR}$, Bangalore, India) at $480 \mathrm{~nm}$. The bacterial culture and MHB was used as the negative control.

\subsection{Determining the Production of Exopolysaccharide by Ruthenium Red Staining}

To determine the activity of L. rhamnosus crude biosurfactant in diminishing the EPS matrix production of biofilm, a Ruthenium red staining assay was carried out [92]. The logphase culture of each test strain $(100 \mu \mathrm{L})$ and L. rhamnosus crude biosurfactant (MIC) were incubated for $24 \mathrm{~h}$ at $37^{\circ} \mathrm{C}$. After the incubation period, planktonic cells were discarded by washing thrice with sterile PBS $(200 \mu \mathrm{L})$. Formed and structured biofilms by the adherent cells were then stained with $0.01 \%$ Ruthenium red (Sigma-Aldrich ${ }^{\circledR}$, Bangalore, India) $(200 \mu \mathrm{L})$. One well without biofilm and with Ruthenium red served as the blanks. Plates were then kept for incubation at $37^{\circ} \mathrm{C}$ for $1 \mathrm{~h}$. Liquid holding the residual stain was resettled in a new microtiter plate and the absorbance was read at $450 \mathrm{~nm}$. The quantity of the dye fixed to the biofilm matrix was measured as follows:

$$
\mathrm{Abs}_{\mathrm{BF}}=\mathrm{Abs}_{\mathrm{B}}-\mathrm{Abs}_{\mathrm{S}}
$$


where $\mathrm{Abs}_{\mathrm{B}}=$ absorbance of the blanks, and $\mathrm{Abs}_{\mathrm{S}}=$ absorbance of the residual stain collected from the sample wells

\subsection{Gas Chromatography-Mass Spectophotometry (GC-MS) Analysis}

The identification of the structural analog of the crude biosurfactant was carried out

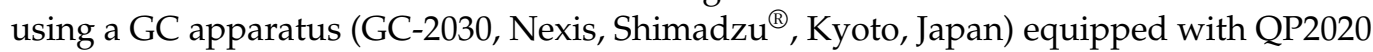
NX-MS. A total of $10 \mu \mathrm{L}$ of the sample was injected into the system and helium was used as a carrier gas. A flow rate of $1 \mathrm{~mL} / \mathrm{min}$ was used and the run time was $20 \mathrm{~min}$. The oven temperature was kept between $60^{\circ} \mathrm{C}$ and $260{ }^{\circ} \mathrm{C}$. The MS of the detected compounds was compared with the National Institute of Standards and Technology (NIST) database.

\section{Conclusions}

Collectively, this study revealed that the L. rhamnosus-derived biosurfactant has significant antibacterial potential against diverse Gram-positive and Gram-negative pathogenic bacteria. The crude biosurfactant derived from L. rhamnosus also displayed potent inhibition of biofilm and bacterial adhesion via influencing the viability and integrity of the bacterial cells within the biofilms, as well as by hampering the production of EPS. These findings indicate that the L. rhamnosus crude biosurfactant can potentially be useful or can become a potent antibacterial and antibiofilm compound, as an alternative to antibiotics or other chemically synthesized toxic agents. Hence, we recommend more investigations to be conducted to have a better understanding about the broad action of crude biosurfactants, before efforts are made to develop its pharmaceutical/industrial applications.

Author Contributions: Conceptualization, M.P. and M.A. (Mohd Adnan); Data curation, M.P., A.J.S., W.S.H., M.S. (Malvi Surti), A.M.A., S.A.A., M.A. (Mousa Alreshidi), M.S. (Mejdi Snoussi), S.M.D.R., F.B., A.J. and M.S. (Manojkumar Sachidanandan); Formal analysis, M.P., A.J.S., M.S. (Malvi Surti), M.A. (Mousa Alreshidi), M.S. (Mejdi Snoussi) and F.B.; Investigation, W.S.H., S.A.A., M.A. (Mousa Alreshidi), M.S. (Mejdi Snoussi) and A.J.; Methodology, W.S.H., M.S. (Malvi Surti), A.M.A., S.A.A., M.S. (Mejdi Snoussi), S.M.D.R. and A.J.; Project administration, M.A. (Mohd Adnan); Software, A.J.S. and M.S. (Manojkumar Sachidanandan); Supervision, M.A. (Mohd Adnan); Validation, A.M.A., M.A. (Mousa Alreshidi), F.B., A.J. and M.S. (Manojkumar Sachidanandan); Visualization, A.J.S., W.S.H., A.M.A. and S.M.D.R.; Writing-Original draft, M.P. and M.A. (Mohd Adnan); Writing-Review \& editing, M.S. (Malvi Surti), S.A.A., S.M.D.R., F.B., M.S. (Manojkumar Sachidanandan) and M.A. (Mohd Adnan). All authors have read and agreed to the published version of the manuscript.

Funding: This research has been funded by Scientific Research Deanship at University of Ha'il, Saudi Arabia through project number RG-20094.

Institutional Review Board Statement: Not applicable.

Informed Consent Statement: Not applicable.

Data Availability Statement: All data generated or analyzed during this study are included in this article.

Conflicts of Interest: The authors declare no conflict of interest. The funders had no role in the design of the study; in the collection, analyses, or interpretation of data; in the writing of the manuscript, or in the decision to publish the results.

\section{References}

1. Adnan, M.; Patel, M.; Deshpande, S.; Alreshidi, M.; Siddiqui, A.J.; Reddy, M.N.; Emira, N.; De Feo, V. Effect of Adiantum philippense Extract on Biofilm Formation, Adhesion With Its Antibacterial Activities Against Foodborne Pathogens, and Characterization of Bioactive Metabolites: An in vitro-in silico Approach. Front. Microbiol. 2020, 11, 823. [CrossRef] [PubMed]

2. Donlan, R.M. Biofilm Formation: A Clinically Relevant Microbiological Process. Clin. Infect. Dis. 2001, 33, 1387-1392. [CrossRef]

3. Ceri, H.; Olson, M.; Stremick, C.; Read, R.R.; Morck, D.; Buret, A. The Calgary Biofilm Device: New Technology for Rapid Determination of Antibiotic Susceptibilities of Bacterial Biofilms. J. Clin. Microbiol. 1999, 37, 1771-1776. [CrossRef] [PubMed]

4. del Pozo, J.L.; Patel, R. The Challenge of Treating Biofilm-associated Bacterial Infections. Clin. Pharmacol. Ther. 2007, 82, 204-209. [CrossRef] 
5. Bui, L.M.; Turnidge, J.D.; Kidd, S.P. The induction of Staphylococcus aureus biofilm formation or Small Colony Variants is a strain-specific response to host-generated chemical stresses. Microbes Infect. 2015, 17, 77-82. [CrossRef] [PubMed]

6. Begun, J.; Gaiani, J.M.; Rohde, H.; Mack, D.; Calderwood, S.B.; Ausubel, F.M.; Sifri, C.D. Staphylococcal Biofilm Exopolysaccharide Protects against Caenorhabditis elegans Immune Defenses. PLOS Pathog. 2007, 3, e57. [CrossRef]

7. Prabhakara, R.; Harro, J.M.; Leid, J.G.; Keegan, A.D.; Prior, M.L.; Shirtliff, M.E. Suppression of the Inflammatory Immune Response Prevents the Development of Chronic Biofilm Infection Due to Methicillin-Resistant Staphylococcus aureus. Infect. Immun. 2011, 79, 5010-5018. [CrossRef]

8. Hausner, M.; Wuertz, S. High Rates of Conjugation in Bacterial Biofilms as Determined by Quantitative In Situ Analysis. Appl. Environ. Microbiol. 1999, 65, 3710-3713. [CrossRef]

9. Parsek, M.R.; Singh, P.K. Bacterial Biofilms: An Emerging Link to Disease Pathogenesis. Annu. Rev. Microbiol. 2003, 57, 677-701. [CrossRef]

10. Adnan, M.; Alshammari, E.; Patel, M.; Ashraf, S.A.; Khan, S.; Hadi, S. Significance and potential of marine microbial natural bioactive compounds against biofilms/biofouling: Necessity for green chemistry. PeerJ 2018, 6, e5049. [CrossRef]

11. Van Delden, C.; Iglewski, B.H. Cell-to-cell signaling and Pseudomonas aeruginosa infections. Emerg. Infect. Dis. 1998, 4, 551-560. [CrossRef]

12. Ron, E.Z.; Rosenberg, E. Natural roles of biosurfactants. Minireview. Environ. Microbiol. 2001, 3, 229-236. [CrossRef] [PubMed]

13. Mulligan, C.N. Environmental applications for biosurfactants. Environ. Pollut. 2005, 133, 183-198. [CrossRef]

14. Sen, R. Surfactin: Biosynthesis, Genetics and Potential Applications. Biosurfactants 2010, 672, 316-323. [CrossRef]

15. Benincasa, M.; Abalos, A.; Oliveira, I.; Manresa, A. Chemical structure, surface properties and biological activities of the bio-surfactant produced by Pseudomonas aeruginosa LBI from soapstock. Antonie Van Leeuwenhoek 2004, 85, 1-8. [CrossRef] [PubMed]

16. Rofeal, M.; El-Malek, F.A. Valorization of Lipopeptides Biosurfactants as Anticancer Agents. Int. J. Pept. Res. Ther. 2021, 27, 447-455. [CrossRef]

17. Rodrigues, L.R.; Banat, I.M.; Van Der Mei, H.C.; Teixeira, J.A.; Oliveira, R. Interference in adhesion of bacteria and yeasts isolated from explanted voice prostheses to silicone rubber by rhamnolipid biosurfactants. J. Appl. Microbiol. 2006, 100, 470-480. [CrossRef] [PubMed]

18. Mulligan, C.N.; Sharma, S.K.; Mudhoo, A. Biosurfactants: Research Trends and Applications; CRC Press: Boca Raton, FL, USA, 2019.

19. Satputea, S.K.; Banpurkar, A.G.; Banat, I.M.; Sangshetti, J.N.; Patil, R.H.; Gade, W.N. Multiple Roles of Biosurfactants in Biofilms. Curr. Pharm. Des. 2016, 22, 1429-1448. [CrossRef]

20. Ceresa, C.; Tessarolo, F.; Caola, I.; Nollo, G.; Cavallo, M.; Rinaldi, M.; Fracchia, L. Inhibition of Candida albicans adhesion on medical-grade silicone by a Lactobacillus -derived biosurfactant. J. Appl. Microbiol. 2015, 118, 1116-1125. [CrossRef]

21. Sharma, D.; Saharan, B.S. Simultaneous Production of Biosurfactants and Bacteriocins by ProbioticLactobacillus caseiMRTL3. Int. J. Microbiol. 2014, 2014, 1-7. [CrossRef] [PubMed]

22. Thavasi, R.; Jayalakshmi, S.; Banat, I.M. Effect of biosurfactant and fertilizer on biodegradation of crude oil by marine isolates of Bacillus megaterium, Corynebacterium kutscheri and Pseudomonas aeruginosa. Bioresour. Technol. 2011, 102, 772-778. [CrossRef]

23. Gudiña, E.J.; Teixeira, J.A.; Rodrigues, L.R. Biosurfactant-Producing Lactobacilli: Screening, Production Profiles, and Effect of Medium Composition. Appl. Environ. Soil Sci. 2011, 2011, 1-9. [CrossRef]

24. Saravanakumari, P.; Mani, K. Structural characterization of a novel xylolipid biosurfactant from Lactococcus lactis and analysis of antibacterial activity against multi-drug resistant pathogens. Bioresour. Technol. 2010, 101, 8851-8854. [CrossRef] [PubMed]

25. Falagas, M.; Makris, G. Probiotic bacteria and biosurfactants for nosocomial infection control: A hypothesis. J. Hosp. Infect. 2009, 71, 301-306. [CrossRef]

26. Rivera, O.M.P.; Moldes, A.B.; Torrado, A.M.; Domínguez, J.M. Lactic acid and biosurfactants production from hydrolyzed distilled grape marc. Process. Biochem. 2007, 42, 1010-1020. [CrossRef]

27. Rodrigues, L.; Banat, I.; Teixeira, J.; Oliveira, R. Biosurfactants: Potential applications in medicine. J. Antimicrob. Chemother. 2006, 57, 609-618. [CrossRef] [PubMed]

28. Rodrigues, L.; van der Mei, H.C.; Teixeira, J.; Oliveira, R. Influence of Biosurfactants from Probiotic Bacteria on Formation of Biofilms on Voice Prostheses. Appl. Environ. Microbiol. 2004, 70, 4408-4410. [CrossRef]

29. Servin, A.L. Antagonistic activities of lactobacilli and bifidobacteria against microbial pathogens. FEMS Microbiol. Rev. 2004, 28, 405-440. [CrossRef]

30. Heinemann, C.; van Hylckama Vlieg, J.E.; Janssen, D.B.; Busscher, H.J.; van der Mei, H.C.; Reid, G. Purification and characterization of a surface-binding protein from Lactobacillus fermentum RC-14 that inhibits adhesion of Enterococcus faecalis 1131. FEMS Microbiol. Lett. 2000, 190, 177-180. [CrossRef] [PubMed]

31. Wuyts, S.; Wittouck, S.; De Boeck, I.; Allonsius, C.N.; Pasolli, E.; Segata, N.; Lebeer, S. Large-scale phylogenomics of the Lac-tobacillus casei group highlights taxonomic inconsistencies and reveals novel clade-associated features. MSystems 2017, 2, e00061-17. [CrossRef]

32. Zheng, J.; Wittouck, S.; Salvetti, E.; Franz, C.M.A.P.; Harris, H.M.B.; Mattarelli, P.; O'Toole, P.W.; Pot, B.; Vandamme, P.; Walter, J.; et al. A taxonomic note on the genus Lactobacillus: Description of 23 novel genera, emended description of the genus Lactobacillus Beijerinck 1901, and union of Lactobacillaceae and Leuconostocaceae. Int. J. Syst. Evol. Microbiol. 2020, 70, $2782-2858$. [CrossRef] 
33. Liu, D.D.; Gu, C.T. Proposal to reclassify Lactobacillus zhaodongensis, Lactobacillus zeae, Lactobacillus argentoratensis and Lactobacillus buchneri subsp. silagei as Lacticaseibacillus zhaodongensis comb. nov., Lacticaseibacillus zeae comb. nov., Lactiplantibacillus argentoratensis comb. nov. and Lentilactobacillus buchneri subsp. silagei comb. nov., respectively and Apilactobacillus kosoi as a later heterotypic synonym of Apilactobacillus micheneri. Int. J. Syst. Evol. Microbiol. 2020, 70, 6414-6417.

34. Skerman, V.B.D.; McGowan, V.; Sneath, P.H.A. Approved lists of bacterial names. Int. J. Syst. Evol. Microbiol. 1980, 30, 225-420. [CrossRef]

35. Collins, M.D.; Phillips, B.A.; Zanoni, P. Deoxyribonucleic Acid Homology Studies of Lactobacillus casei, Lactobacillus paracasei sp. nov., subsp. paracasei and subsp. tolerans, and Lactobacillus rhamnosus sp. nov., comb. nov. Int. J. Syst. Evol. Microbiol. 1989, 39, 105-108. [CrossRef]

36. Jara, S.; Sánchez, M.; Vera, R.; Cofré, J.; Castro, E. The inhibitory activity of Lactobacillus spp. isolated from breast milk on gastrointestinal pathogenic bacteria of nosocomial origin. Anaerobe 2011, 17, 474-477. [CrossRef]

37. Martín, R.; Langa, S.; Reviriego, C.; Jiménez, E.; Marín, M.L.; Xaus, J.; Fernández, L.; Rodríguez, J.M. Human milk is a source of lactic acid bacteria for the infant gut. J. Pediatr. 2003, 143, 754-758. [CrossRef] [PubMed]

38. Martín, R.; Langa, S.; Reviriego, C.; Jiménez, E.; Marín, M.L.; Olivares, M.; Boza, J.; Jiménez, J.; Fernández, L.; Xaus, J.; et al. The commensal microflora of human milk: New perspectives for food bacteriotherapy and probiotics. Trends Food Sci. Technol. 2004, 15, 121-127. [CrossRef]

39. Heikkila, M.P.; Saris, P.E.J. Inhibition of Staphylococcus aureus by the commensal bacteria of human milk. J. Appl. Microbiol. 2003, 95, 471-478. [CrossRef]

40. Patel, K.; Patel, M. Improving bioremediation process of petroleum wastewater using biosurfactants producing Stenotrophomonas sp. S1VKR-26 and assessment of phytotoxicity. Bioresour. Technol. 2020, 315, 123861. [CrossRef]

41. Adnan, M.; Alshammari, E.; Ashraf, S.A.; Patel, K.; Lad, K.; Patel, M. Physiological and molecular characterization of biosurfactant producing endophytic fungi Xylaria regalis from the cones of Thuja plicata as a potent plant growth promoter with its potential application. BioMed Res. Int. 2018, 2018. [CrossRef]

42. Singh, P.; Cameotra, S.S. Potential applications of microbial surfactants in biomedical sciences. Trends Biotechnol. 2004, 22, 142-146. [CrossRef]

43. Kracht, M.; Rokos, H.; Özel, M.; Kowall, M.; Pauli, G.; Vater, J. Antiviral and Hemolytic Activities of Surfactin Isoforms and Their Methyl Ester Derivatives. J. Antibiot. 1999, 52, 613-619. [CrossRef] [PubMed]

44. Fracchia, L.; Cavallo, M.; Martinotti, M.G.; Banat, I.M. Biosurfactants and bioemulsifiers biomedical and related applica-tionspresent status and future potentials. Biomed. Sci. Eng. Technol. 2012, 14, 326-335.

45. Quadriya, H.; Ali, S.A.M.; Parameshwar, J.; Manasa, M.; Khan, M.Y.; Hameeda, B. Microbes Living Together: Exploiting the Art for Making Biosurfactants and Biofilms. In Implication of Quorum Sensing System in Biofilm Formation and Virulence; Springer: Berlin/Heidelberg, Germany, 2018; pp. 161-177.

46. Abisado, R.; Benomar, S.; Klaus, J.; Dandekar, A.; Chandler, J. Bacterial Quorum Sensing and Microbial Community Interac-tions. mBio 2018, 9, e02331-17.

47. Mangwani, N.; Kumari, S.; Das, S. Bacterial biofilms and quorum sensing: Fidelity in bioremediation technology. Biotechnol. Genet. Eng. Rev. 2016, 32, 43-73. [CrossRef] [PubMed]

48. Velraeds, M.M.; van der Mei, H.C.; Reid, G.; Busscher, H.J. Inhibition of initial adhesion of uropathogenic Enterococcus faecalis by biosurfactants from Lactobacillus isolates. Appl. Environ. Microbiol. 1996, 62, 1958-1963. [CrossRef]

49. Dusane, D.; Rajput, J.; Kumar, A.; Nancharaiah, Y.; Venugopalan, V.; Zinjarde, S. Disruption of fungal and bacterial biofilms by lauroyl glucose. Lett. Appl. Microbiol. 2008, 47, 374-379. [CrossRef] [PubMed]

50. Dusane, D.; Nancharaiah, Y.V.; Zinjarde, S.S.; Venugopalan, V.P. Rhamnolipid mediated disruption of marine Bacillus pumilus biofilms. Colloids Surfaces B Biointerfaces 2010, 81, 242-248. [CrossRef] [PubMed]

51. Rivardo, F.; Turner, R.J.; Allegrone, G.; Ceri, H.; Martinotti, M.G. Anti-adhesion activity of two biosurfactants produced by Bacillus spp. prevents biofilm formation of human bacterial pathogens. Appl. Microbiol. Biotechnol. 2009, 83, 541-553. [CrossRef] [PubMed]

52. Amaral, P.; Da Silva, J.; Lehocky, b.M.; Barros-Timmons, A.; Coelho, M.; Marrucho, I.; Coutinho, J. Production and characterization of a bioemulsifier from Yarrowia lipolytica. Process. Biochem. 2006, 41, 1894-1898. [CrossRef]

53. De JesusCortés-Sánchez, A.; Hernández-Sánchez, H.; Jaramillo-Flores, M.E. Biological activity of glycolipids produced by microorganisms: New trends and possible therapeutic alternatives. Microbiol. Res. 2013, 168, 22-32. [CrossRef]

54. Mulligan, C.N.; Gibbs, B.F. Types, production and applications of biosurfactants. Proc. Indian Natl. Sci. Acad. Part B 2004, 70, 31-56.

55. Pinto, S.; Alves, P.; Santos, A.; Matos, C.; Oliveiros, B.; Gonçalves, S.; Gudiña, E.; Rodrigues, L.; Teixeira, J.; Gil, M. Poly (di-methyl siloxane) surface modification with biosurfactants isolated from probiotic strains. J. Biomed. Mater. Re-Search Part A 2011, 98, 535-543. [CrossRef]

56. Hua, Z.; Chen, J.; Lun, S.; Wang, X. Influence of biosurfactants produced by Candida antarctica on surface properties of mi-croorganism and biodegradation of n-alkanes. Water Res. 2003, 37, 4143-4150. [CrossRef]

57. Satpute, S.; Bhawsar, B.; Dhakephalkar, P.; Chopade, B. Assessment of different screening methods for selecting biosurfactant producing marine bacteria. Indian J. Geo-Mar. Sci. 2008, 37, 243-250. 
58. Neu, T.R. Significance of bacterial surface-active compounds in interaction of bacteria with interfaces. Microbiol. Rev. 1996, 60, 151-166. [CrossRef]

59. Tahmourespour, A.; Salehi, R.; Kermanshahi, R.K.; Eslami, G. The anti-biofouling effect ofLactobacillus fermentum-derived biosurfactant againstStreptococcus mutans. Biofouling 2011, 27, 385-392. [CrossRef] [PubMed]

60. Lemos, A.S.O.; Campos, L.M.; Melo, L.; Guedes, M.C.M.R.; Oliveira, L.G.; Silva, T.P.; Melo, R.; Rocha, V.N.; Aguiar, J.; Apolonio, A.C.; et al. Antibacterial and Antibiofilm Activities of Psychorubrin, a Pyranonaphthoquinone Isolated from Mitracarpus frigidus (Rubiaceae). Front. Microbiol. 2018, 9, 724. [CrossRef]

61. Leme, A.P.; Koo, H.; Bellato, C.M.; Bedi, G.; Cury, J.A. The Role of Sucrose in Cariogenic Dental Biofilm Formation-New Insight. J. Dent. Res. 2006, 85, 878-887. [CrossRef]

62. Kim, D.; Hwang, G.; Liu, Y.; Wang, Y.; Singh, A.P.; Vorsa, N.; Koo, H. Cranberry Flavonoids Modulate Cariogenic Properties of Mixed-Species Biofilm through Exopolysaccharides-Matrix Disruption. PLoS ONE 2015, 10, e0145844. [CrossRef]

63. Lentino, J.R. Prosthetic Joint Infections: Bane of Orthopedists, Challenge for Infectious Disease Specialists. Clin. Infect. Dis. 2003, 36, 1157-1161. [CrossRef]

64. Parkinson, M. Bio-surfactants. Biotechnol. Adv. 1985, 3, 65-83. [CrossRef]

65. van Hoogmoed, C.G.; van der Kuijl-Booij, M.; van der Mei, H.C.; Busscher, H.J. Inhibition of Streptococcus mutans NS Adhesion to Glass with and without a Salivary Conditioning Film by Biosurfactant- Releasing Streptococcus mitis Strains. Appl. Environ. Microbiol. 2000, 66, 659-663. [CrossRef] [PubMed]

66. Ramage, G.; Walle, K.V.; Wickes, B.; López-Ribot, J.L. Standardized Method for In Vitro Antifungal Susceptibility Testing of Candida albicans Biofilms. Antimicrob. Agents Chemother. 2001, 45, 2475-2479. [CrossRef]

67. Walencka, E.; Różalska, S.; Sadowska, B. The influence of Lactobacillus acidophilus-derived surfactants on staphylococcal adhesion and biofilm formation. Folia Microbiol. 2008, 53, 61-66. [CrossRef]

68. Augustine, N.; Kumar, P.; Thomas, S. Inhibition of Vibrio cholerae biofilm by AiiA enzyme produced from Bacillus spp. Arch. Microbiol. 2010, 192, 1019-1022. [CrossRef]

69. Sambanthamoorthy, K.; Feng, X.; Patel, R.; Patel, S.; Paranavitana, C. Antimicrobial and antibiofilm potential of biosurfactants isolated from lactobacilli against multi-drug-resistant pathogens. BMC Microbiol. 2014, 14, 197. [CrossRef]

70. Gudiña, E.J.; Rocha, V.; Teixeira, J.A.; Rodrigues, L.R. Antimicrobial and antiadhesive properties of a biosurfactant isolated from Lactobacillus paracasei ssp. paracaseiA20. Lett. Appl. Microbiol. 2010, 50, 419-424. [CrossRef]

71. Fracchia, L.; Cavallo, M.; Allegrone, G.; Martinotti, M.G. Lactobacillus-derived biosurfactant inhibits biofilm formation of human pathogenic Candida albicans biofilm producers. Appl. Microbiol. Microb. Biotechnol. 2010, 210, 827-837.

72. Van Der Mei, H.; Free, R.; Van Weissenbruch, R.; Busscher, H.; Elving, G.; Albers, F.J. Effect of probiotic bacteria on prevalence of yeasts in oropharyngeal biofilms on silicone rubber voice prostheses in vitro. J. Med Microbiol. 2000, 49, 713-718. [CrossRef]

73. Kiran, G.S.; Priyadharsini, S.; Sajayan, A.; Ravindran, A.; Selvin, J. An antibiotic agent pyrrolo[1,2-a]pyrazine-1,4-dione,hexahydro isolated from a marine bacteria Bacillus tequilensis MSI45 effectively controls multi-drug resistant Staphylococcus aureus. RSC Adv. 2018, 8, 17837-17846. [CrossRef]

74. Hassan, F.; Nasibullah, M.; Ahmad, N.; Kamal, A.; Rizvi, S.M.D.; Khan, M.S.; Khan, A.R. Synthesis, Characterization and Physicochemical Analysis of some Mannofuranoside Derivatives with Potent Antimicrobial Activity. Orient. J. Chem. 2017, 33, 2731-2741. [CrossRef]

75. Arancibia, L.; Naspi, C.; Pucci, G.; Arce, M.; Colloca, C. Biological activity of 1-heneicosanol isolated from Senecio coluhua-piensis, an endemic species from Patagonia, Argentina. Pharm. Chem. J. 2016, 3, 73-77.

76. Poongulali, S.; Sundararaman, M. Antimycobacterial, anticandidal and antioxidant properties of Terminalia catappa and analysis of their bioactive chemicals. Int. J. Pharm. Biol. Sci. 2016, 6, 69-83.

77. Okwu, D.E.; Ighodaro, B.U. GC-MS evaluation of bioactive compounds and antibacterial activity of the oil fraction from the leaves of Alstonia boonei De Wild. Der Pharma Chem. 2010, 2, 261-272.

78. Rouis-Soussi, L.S.; Ayeb-Zakhama, E.A.; Mahjoub, A.; Flamini, G.; Ben Jannet, H.; Harzallah-Skhiri, F. Chemical composition and antibacterial activity of essential oils from the Tunisian Allium nigrum L. EXCLI J. 2014, 13, 526. [CrossRef]

79. Abubakar, M.N.; Majinda, R.R.T. GC-MS Analysis and Preliminary Antimicrobial Activity of Albizia adianthifolia (Schumach) and Pterocarpus angolensis (DC). Medicines 2016, 3, 3. [CrossRef]

80. de Carvalho, M.P.; Abraham, W.-R. Antimicrobial and biofilm inhibiting diketopiperazines. Curr. Med. Chem. 2012, 19, 3564-3577. [CrossRef]

81. Green, M.R.; Sambrook, J. Molecular Cloning: A Laboratory Manual; Cold Spring Harbour Laboratory: Cold Spring Harbor, NY, USA, 2012.

82. Satpute, S.K.; Banpurkar, A.G.; Dhakephalkar, P.K.; Banat, I.M.; Chopade, B.A. Methods for investigating biosurfactants and bioemulsifiers: A review. Crit. Rev. Biotechnol. 2010, 30, 127-144. [CrossRef]

83. Płaza, G.A.; Zjawiony, I.; Banat, I.M. Use of different methods for detection of thermophilic biosurfactant-producing bacteria from hydrocarbon-contaminated and bioremediated soils. J. Pet. Sci. Eng. 2006, 50, 71-77. [CrossRef]

84. Joe, M.M.; Gomathi, R.; Benson, A.; Shalini, D.; Rengasamy, P.; Henry, A.J.; Truu, J.; Truu, M.; Sa, T. Simultaneous Application of Biosurfactant and Bioaugmentation with Rhamnolipid-Producing Shewanella for Enhanced Bioremediation of Oil-Polluted Soil. Appl. Sci. 2019, 9, 3773. [CrossRef] 
85. Wiegand, I.; Hilpert, K.; Hancock, R.E.W. Agar and broth dilution methods to determine the minimal inhibitory concentration (MIC) of antimicrobial substances. Nat. Protoc. 2008, 3, 163-175. [CrossRef]

86. Silveira, C.P.; Torres-Rodríguez, J.M.; Alvarado-Ramírez, E.; Murciano-Gonzalo, F.; Dolande, M.; Panizo, M.; Reviakina, V. MICs and minimum fungicidal concentrations of amphotericin B, itraconazole, posaconazole and terbinafine in Sporothrix schenckii. J. Med. Microbiol. 2009, 58, 1607-1610. [CrossRef]

87. Lee, K.W.K.; Periasamy, S.; Mukherjee, M.; Xie, C.; Kjelleberg, S.; Rice, S.A. Biofilm development and enhanced stress resistance of a model, mixed-species community biofilm. ISME J. 2013, 8, 894-907. [CrossRef] [PubMed]

88. Plyuta, V.; Zaitseva, J.; Lobakova, E.; Zagoskina, N.; Kuznetsov, A.; Khmel, I. Effect of plant phenolic compounds on biofilm formation byPseudomonas aeruginosa. APMIS 2013, 121, 1073-1081. [CrossRef] [PubMed]

89. Musthafa, K.S.; Ravi, A.V.; Annapoorani, A.; Packiavathy, S.V.; Pandian, S.K. Evaluation of Anti-Quorum-Sensing Activity of Edible Plants and Fruits through Inhibition of the N-Acyl-Homoserine Lactone System in Chromobacterium violaceum and Pseudomonas aeruginosa. Chemotherapy 2010, 56, 333-339. [CrossRef]

90. Nett, J.E.; Cain, M.; Crawford, K.; Andes, D. Optimizing a Candida Biofilm Microtiter Plate Model for Measurement of Antifungal Susceptibility by Tetrazolium Salt Assay. J. Clin. Microbiol. 2011, 49, 1426-1433. [CrossRef] [PubMed]

91. Siddiqui, A.J.; Bhardwaj, J.; Goyal, M.; Prakash, K.; Adnan, M.; Alreshidi, M.M.; Patel, M.; Soni, A.; Redman, W. Immune responses in liver and spleen against Plasmodium yoelii pre-erythrocytic stages in Swiss mice model. J. Adv. Res. 2020, $24,29-41$. [CrossRef]

92. Borucki, M.K.; Krug, M.J.; Muraoka, W.T.; Call, D.R. Discrimination among Listeria monocytogenes isolates using a mixed genome DNA microarray. Veter-Microbiol. 2003, 92, 351-362. [CrossRef] 